\title{
The long-run determinants of inequality: What can we learn from top income data?*
}

\author{
Jesper Roine ${ }^{\dagger}$, Jonas Vlachos ${ }^{\ddagger}$ and Daniel Waldenström*
}

March 25, 2009

\begin{abstract}
This paper studies determinants of income inequality using a newly assembled panel of 16 countries over the entire twentieth century. We focus on three groups of income earners: the rich (P99-100), the upper middle class (P90-99), and the rest of the population (P0-90). The results show that periods of high economic growth disproportionately increases the top percentile income share at the expense of the rest of the top decile. Financial development is also pro-rich and the outbreak of banking crises is associated with reduced income shares of the rich. Trade openness has no clear distributional impact (if anything openness reduces top shares). Government spending, however, is negative for the upper middle class and positive for the nine lowest deciles but does not seem to affect the rich. Finally, tax progressivity reduces top income shares and when accounting for real dynamic effects the impact can be important over time.
\end{abstract}

Keywords: Top incomes, income inequality, financial development, trade openness, government spending, taxation, economic development

JEL: D31, F10, G10, H20, N30

\footnotetext{
${ }^{*}$ We would like to thank three anonymous referees, Tony Atkinson, Thorsten Beck, Robert Gordon, Henrik Jordahl, Thomas Piketty, Kristian Rydqvist and seminar participants at Université Libre de Bruxelles, 3rd BETA workshop in Strasbourg, 2007 ETSG in Athens and 4th DG ECFIN Research Conference in Brussels 2007 for useful comments. Thanks also to Michael Clemens and Jakob Madsen for kindly sharing their data with us. Financial support from the Jan Wallander and Tom Hedelius Foundation and the Gustaf Douglas Research Program on entrepreneurship at IFN is gratefully acknowledged.

${ }^{\dagger}$ SITE, Stockholm School of Economics, P.O. Box 6501, SE-11383 Stockholm, Ph: +46-8-7369682, jesper.roine@hhs.se

"Department of Economics, CEPR \& IFN, Stockholm University, SE-10691 Stockholm. Ph: +46-8163046, jonas.vlachos@ne.su.se.

* Research Institute of Industrial Economics (IFN), P.O. Box 55665, SE-10215 Stockholm, Ph: +46-86654531, danielw@ifn.se.
} 


\section{Introduction}

The relationship between inequality and development is central in the study of economics. From fundamental issues about whether markets forces have an innate tendency to increase or decrease differences in economic outcomes, to much debated questions about the effects of "globalization", distributional concerns are always present: Does economic growth really benefit everyone equally or does it come at the price of increased inequality? Is the effect perhaps different over the path of development? Is it the case that increased openness benefits everyone equally, is it perhaps especially the poor that gain, or is it the case that it strengthens the position only of those who can take full advantage of increased international trade? Does financial development really increase the opportunities for previously credit constrained individuals or does it only create increased opportunities for the already rich? What is the role of government in all this? Theoretically such questions are difficult to resolve as there are plausible models suggesting equalizing effects from these developments, as well as models suggesting the opposite. ${ }^{1}$ Empirically problems often arise because these effects should be evaluated over long periods of time and data is typically only available for relatively short periods.

This paper empirically examines the long-run associations between income inequality and economic growth, financial development, trade openness, top marginal tax rates, and the size of government. ${ }^{2}$ While these variables are not direct measures of typically suggested causes of changes in income distribution, such as globalization, technological change or social norms, studying their relation to inequality over time seems as an important step toward understanding such broader concepts. The main novelties of our study lie in the uniquely long time period for which we have data and in the focus

\footnotetext{
${ }^{1}$ Just to give some examples: one may distinguish between theories that predict markets to be innately equalizing, disequalizing or both (depending on initial conditions). Mookherjee and Ray (2006) give a useful overview of the literature on development and endogenous inequality based on such a division. Winters et al. (2004) give an overview of evidence on the relation between trade and inequality, Cline (1997) summarizes different theoretical effects of trade on income distribution, while Claessens and Perotti (2005) provide references for the links between finance and inequality, presenting theories which suggest both equalizing effects as well as the opposite. We will discuss some of the suggested mechanisms in more detail in Section 2 below.

${ }^{2}$ As our focus is on pre-tax income we do not explicitly address questions of redistributive policy but rather the effects of taxes and government size on income before taxes and transfers. See Bardhan, Bowles and Wallerstein (eds.), 2006, for several contributions on the relation between various facets of globalization and their impact on the possibilities to redistribute income).
} 
on top income shares. We use the newly compiled Atkinson-Piketty dataset for 16 countries over the whole of the twentieth century (see Atkinson and Piketty, 2007, 2009). ${ }^{3}$ While previous studies have only had comparable data from the 1960s (at best), our series begin at the end of the "first wave" of globalization (1870-1913), continues over the interwar de-globalization era (1913-1950), the postwar "golden age" (1950-1973) and ends with the current "second wave" of globalization. ${ }^{4}$ Hence, in contrast to relying on shorter periods of broader cross-country evidence, our dataset allows us to study how inequality has changed over a full wave of shifts in openness as well as several major developments in the financial sector. In terms of the role of government, our long period of analysis implies that we basically cover the entire expansion of the public sector and the same is true for the role of income taxation, which was non-existent or negligible at the beginning of the twentieth century. ${ }^{5}$

The focus on top incomes, and on concentration within the top, means that we can address a special subset of questions regarding the extent to which economic development is particularly pro-rich. ${ }^{6}$ More precisely, our data allows us to distinguish between the effects on, broadly speaking, the "rich" (top executives and individuals with important shares of capital income), the "upper middle class" (high income wage earners), and the rest of the population. ${ }^{7}$ As has frequently been pointed out in the recent top income literature the top decile is a very heterogeneous group. The lower

\footnotetext{
${ }^{3}$ Even though the choice of countries - mostly developed economies - is mainly a result of data availability it has some positive side effects. We are, for example, able to trace a fixed set of relatively similar countries as they develop rather than letting different countries represent stages of development. Having similar countries is also important especially when thinking about theoretical predictions from openness which are often diametrically different for countries with different factor endowments, technology levels etc. Parallel to our work, Andrews, Jencks, and Leigh (2008) also use the new top income inequality data to study the relation between inequality and growth, while we focus on determinants of inequality.

${ }^{4}$ These periods are quoted in, for example, O'Rourke and Williamson (2000), O'Rourke (2001), and Bourguignon and Morrison (2002). These studies discuss various aspects of globalization and inequality over these early periods but they did not have sufficient data to analyze developments in detail. Also see Cornia (2003) for a discussion of differences in within-country inequality between the first and second globalization.

${ }^{5}$ In fact, the introduction of a modern tax system is typically what limits the availability of data on income concentration.

${ }^{6}$ Examples include, models of how aspects of these developments creates extreme returns to "superstars", or models of capitalists and workers where capitalists benefit disproportionately would, when taken to the data, translate to isolated effects for a small group in the top of the income distribution.

${ }^{7}$ Clearly, any such division is arbitrary but the results are not sensitive to variations in the definitions of these top groups, e.g., by choosing to look at the top 0.5 percent instead of the top percentile as "the rich". Furthermore, data on the composition of incomes indicate clearly that the top percent as a whole is very different from the rest of the top decile, especially with regard to capital income shares (we discuss this in section 3). A similar classification, but with respect to wealth, is made in Hoffman, PostelVinay and Rosenthal (2007).
} 
parts of it typically consists of employed wage earners with relatively stable income shares, while the top has a different composition of income with larger capital shares and with much larger fluctuations over time. ${ }^{8}$ Examining whether some development affects everyone in the top of the distribution in similar ways, or if there are clear differences within the top, holds important keys to what is driving developments of inequality.

Our empirical analysis exploits the variation within countries to examine how changes in top income shares are related to changes in economic development, financial development, trade openness, government expenditure, and taxation. ${ }^{9}$ Using a panel data approach allows us to take all unobservable time-invariant factors, as well as country specific trends into account. We also allow the effects to differ depending on the level of economic development, between Anglo-Saxon countries and others, and between bank- and market-oriented financial systems. ${ }^{10}$

Several findings come out of the analysis. First, we find that periods of high economic growth are strongly pro-rich. In periods when a country's GDP per capita growth has been above average, the income share of the top percentile has also increased. By contrast, the next nine percentiles (P90-99) seem to loose out in these same periods. As we find this relation to be similar at different stages of economic development, it could indicate that recent findings of high productivity growth mainly benefiting the rich in the U.S. postwar era (Dew-Becker and Gordon, 2005, 2007), is a more general phenomenon across both countries and time. This result is in line with top incomes being more responsive to growth (e.g., through compensation being related to profits).

\footnotetext{
${ }^{8}$ For evidence on much of changes in top income concentration stemming from the very top, see Atkinson and Piketty $(2007,2009)$.

${ }^{9}$ We will discuss our empirical strategy in more detail below, but it is important to note, right from the outset, the distinction between our first difference approach and correlations in levels. For example, our result that periods of high growth increases the income share of the rich disproportionately does not imply a positive correlation between growth and top income shares. Indeed a key observation, made in e.g., Piketty (2005) and Piketty and Saez (2006), is that when inequality was at its highest, in the beginning of the Twentieth Century, growth was relatively modest, compared to the post-war period when growth was high and inequality levels low.

${ }^{10}$ As we will discuss in more detail below, these are some of the dimensions in which we may expect differences in development of inequality either on theoretical ground or based on previous empirical findings.
} 
Furthermore, we find that financial development, measured as the relative share of the banking and stock market sectors in the economy, also seems to increase the income share of the top percentile. That these effects are causal is supported by our finding that banking crises a have a strong negative impact on the income shares of the rich (while this is not the case for currency crises). When interacted with the level of economic development it turns out that the result is mostly driven from a strong effect in the early stages of development. This result is in line with the model suggested by Greenwood and Jovanovic (1990) where financial markets initially benefit only the rich but as income levels increase (and with them the development of financial markets) the gains spread down through the distribution. ${ }^{11}$ It is also of particular interest since a recent study by Beck, Demirguc-Kunt and Levine (2007) finds that financial development disproportionately benefits the poor. ${ }^{12}$

Our results with respect to the role of government indicate that government spending as share of GDP has no clear effect on the incomes of the top percentile, but seem to be negative for the upper middle class and positive for the rest of the population. Higher marginal taxes, however, have a robustly negative effect on top income shares both in the top and the bottom of the top decile. ${ }^{13}$ Even though the estimated instantaneous effect is fairly modest, this effect could be sizeable over time. Our simulations of cumulative effects of taxation indicate that they, especially in combination with shocks to capital holdings, can explain large long-run drops in top income shares. ${ }^{14}$.

Finally, with respect to the elusive concept of globalization there are at least two findings that relate to its effects on income inequality. First, openness to trade (the trade share of GDP), which is often used as a measure of 'globalization', does not have a clear effect on inequality, but if anything, seems to have a negative effect on top income shares. Second, the effects of growth can be interpreted as casting doubt on the

\footnotetext{
${ }^{11} \mathrm{We}$ do also find weak support for positive effects of financial development spreading down the distribution over the path of development.

${ }^{12}$ These findings are not necessarily conflicting. For example, both the poor and the richest group can benefit at the expense of the middle. IMF (2007) also finds that financial development is related to increases in income inequality.

${ }^{13}$ This is in line with Atkinson and Leigh (2007c), who find slightly stronger negative effects of marginal taxation on top income shares in their study focusing on Anglo-Saxon countries.

${ }^{14}$ The combination of shocks to capital holdings and increased marginal taxes have been suggested to be a major sources of decreasing top income shares after World War II (see in particular Piketty, 2007, and Piketty and Saez, 2007). Our simulations indicate that our estimated effects are well in line with this type of explanation.
} 
idea that top income earners have their incomes set on a global market while others have theirs set locally. Assuming that domestic development determines incomes on the local labor market while global growth determines the compensation for the elite, domestic economic growth (above the world average) should decrease inequality between the two groups, not increase it as we find. ${ }^{15}$

The remainder of the paper is organized as follows. Section 2 outlines some common theoretical arguments linking the incomes of the rich and the variables included in the study. Section 3 describes the data and their sources while Section 4 provides a brief overview of the relationships between the different variables. Section 5 presents the econometric framework and Section 6 presents the main results and a number of robustness checks. Section 7 concludes.

\section{Potential determinants of trends in top income shares}

A number of recent contributions to the study of income inequality have increased the availability of comparable top income data over the long-run. Following the seminal contribution by Piketty (2001) on the evolution of top income shares in France, series on top income shares over the twentieth century have been constructed for a number of countries using a common methodology. ${ }^{16}$ The focus in this literature has mainly been on establishing facts and to suggest possible explanations for individual countries. To the extent that general themes have been discussed these have focused on accounting for some common trends such as the impact from the Great Depression and World War II (on countries that participated in it) and on the differences between Anglo-Saxon countries and Continental Europe since around 1980.

Broadly speaking the explanations for the sharp drop in top income shares in the first half of the twentieth century have revolved around shocks to capital owners, leading

\footnotetext{
${ }^{15}$ Note that our result is not in conflict with Gersbach and Schmutzler (2007) or Manasse and Turrini (2001) that emphasize the distribution of incomes within the elite group (rather than the average) and predict that globalization leads to an increased spread in incomes for the elite. Others such as Gabaix and Landier (2007) emphasis the firm size effect, while Kaplan and Rauh (2007) stress technological change, superstar effects (Rosen, 1981), and scale effects as plausible explanations for increasing top incomes.

${ }^{16}$ Other recent studies include Australia (Atkinson and Leigh, 2007), Canada (Saez and Veall, 2007), Germany (Dell, 2007), Ireland (Nolan, 2007), Japan (Moriguchi and Saez, 2009), the Netherlands (Atkinson and Salverda, 2007), New Zealand (Atkinson and Leigh, 2007), Spain (Alvaredo and Saez 2007), Sweden (Roine and Waldenström, 2009) and Switzerland (Dell, Piketty and Saez, 2007).
} 
to them losing large parts of the wealth that provided them with much of their income, thus decreasing their income share substantially. High taxes after World War II (and the decades thereafter) prevented the recovery of wealth for these groups. As we will show, our estimates of the effect of top marginal taxes are compatible with this type of explanation. After roughly 1980 top income shares have increased substantially in Anglo-Saxon countries but not in Continental European countries. However, this has not been due to increases in capital incomes but rather due to increased wage inequality (see Piketty and Saez, 2006 for more details on the proposed explanations for the developments).

Even though a number of plausible explanations have been suggested in this literature it is fair to say that, so far, few attempts at exploiting the variation across countries and across time in an econometrically rigorous way has been made. ${ }^{17}$ In fact, in overviews (Piketty 2005 and Piketty and Saez 2006) of this literature it is suggested that even though there will always be severe identification problems - cross country analysis seems a natural next step. A first question when contemplating such an analysis is, of course, what variables that could be expected to have a clear relationship to top income shares. Beside variables suggested in the top income literature, such as growth, taxation and the growth of government, we think variables capturing financial development and openness to trade, are especially interesting.

The next question is; what should we expect these relationships to look like? Here our strategy is to draw on the vast existing literature. As is apparent from the selection of results reviewed below, there are models suggesting positive, negative, as well as nonlinear effects on inequality from just about every variable that we include in our econometric specifications. Our main contribution lies in using data over a uniquely long period to test whether there are robust partial correlations over time, as well as to address the possibility that these relationships may change over the path of development.

\footnotetext{
${ }^{17}$ One paper that does use a panel of top income data is Scheve and Stasavage (2009) that test hypotheses concerning institutional determinants of income inequality (such as wage bargaining centralization, government partisanship, and the presence of an electoral system based on proportional representation).
} 
When it comes to the impact of financial development, it is fair to say that standard theory typically predicts that financial development should decrease inequality, at least if we think of financial development as increasing the availability for previously credit constrained individuals to access capital (or that financial markets allow individuals with initially too little capital to "pool their resources" to be able to reach a critical minimum level needed for an investment). ${ }^{18}$ This is the standard mechanism in growth theories where a country can be caught in a situation where badly developed financial markets make it impossible for much of the population to realize projects that would increase growth (as, for example, in Galor and Zeira, 1993, and in Aghion and Bolton, 1997). The situation would be one of low growth (compared to the country's potential), high inequality and badly developed financial markets. With the development of financial markets, increased growth goes hand in hand with less inequality as the financial markets improve the allocation of resources. A larger fraction of individuals are then given the possibility to realize profitable projects.

There are, however, a number of suggested mechanisms that could turn this prediction around. In an overview of the links between finance and inequality, Claessens and Perotti (2005) give a number of references (e.g., Rajan and Zingales, 2003 and Perotti and Volpin, 2004) to theory, as well as evidence, of financial development, which benefits insiders disproportionately (consequently leading to increased inequality). The idea, in various garbs, is that understanding the potential threat to their position from certain types of development of capital markets, the political elites, implicitly the top income earners, would block such developments, possibly to the detriment of the economy. Hence, these theories agree that in principle the development of financial markets could have an equalizing effect but in practice only developments that disproportionately benefit the elite will materialize.

Beside theories suggesting either increased equality or increased inequality from financial development there are also a number of theories suggesting that financial development, much like the classic Kuznets curve, leads to increased inequality in early stages of development but at later stages also benefits the poor, leading to increased equality. An influential article suggesting precisely this is Greenwood and Jovanovic

\footnotetext{
${ }^{18}$ Recent evidence for financial development being pro-poor is given in Beck, Demirguc-Kunt and Levine (2007).
} 
(1990). Their idea is that at low levels of development when capital markets are nonexistent or at an early stage of development only relatively rich individuals can access the benefits of these (as there are certain fixed costs involved). At this stage further developments of financial markets increase growth but disproportionately benefit the rich. However, as the economy grows richer, a larger and larger portion of the population will be able to access the capital market and more and more individuals will benefit. Consequently resource allocation improves even more, growth continues to increase, but now accompanied by decreasing inequality. Eventually the economy reaches a new steady state where financial markets are fully developed, growth is higher and inequality has gone through a cycle of first increasing and then decreasing over the path of development.

When it comes to standard Heckscher-Ohlin trade theory the inequality effect of openness varies depending on relative factor abundance and productivity differences, and also on the extent to which individuals get income from wages or capital. Easterly (2005) provides a good overview of the arguments, stressing the importance between differences (between countries) stemming from variations in endowments or productivity. Assuming, which seems realistic, that our sample contains countries that (over the whole of the twentieth century) have been relatively capital rich compared to the global average and are places where capital owners coincide with the income rich, we should, in general, expect trade openness to increase the income shares of the rich in our sample. ${ }^{19}$ Even if theory is far from clear cut in its predictions, the basic argument that trade openness - as well as other aspects of globalization - may somehow "naturally" benefit the rich underlie calls for political intervention whereby a "loosing majority" could be compensated given that the total gains are large enough (as shown in Rodrik, 1997). The importance for such compensation has recently forcefully been argued in Scheve and Slaughter, 2007 (see also the recent collection of articles in Bardhan, Bowles and Wallerstein, 2006).

\footnotetext{
${ }^{19}$ An example of when this is not the case would be if differences between countries are due to productivity differences that are so large that the richer countries (the ones in our sample) can export labor intensive goods (productivity advantage offsets labor scarcity). Then trade would reduce inequality in the rich countries. Another potentially important point is the fact that these countries have largely traded with each other, and therefore the predictions could still be different for different countries in our sample.
} 
Looking at the possible effects of taxation the theoretical predictions are again ambiguous. Higher taxes have immediate effects on work incentives and on capital accumulation (and hence on capital income over time) and if these are relatively more important for the top income groups we should expect higher taxes to be negatively related to top income shares. ${ }^{20}$ However, as pointed out in Atkinson (2004), there are theoretical reasons to expect gross income inequality to increase as a result of increased taxation. Even in the simplest model, an increased tax for the rich (or increased progressivity) has a substitution effect causing a decrease in effort but also an income effect pulling in the other direction. Unless this is zero, such an increase should be expected to increase gross income inequality. ${ }^{21}$

Overall, the conclusion we draw from reviewing parts of the literature on possible determinants of top income shares is that theory provides us with many plausible alternatives. The main contribution we can make lies in using the uniquely long period for which we have data to test whether there are robust relationships over time as well as to address issues of changing relationships along the path of development (such as testing whether financial market development has a different effect in early stages of development compared to later stages).

\section{Data description}

This section describes the variables included in the analysis and their sources. Tables 1 and 2 define the variables used and present their sources. ${ }^{22}$ Tables 3 and 4 show summary statistics and pair-wise correlations.

Top income shares. In income inequality research, top income earners are often defined as everyone in the top decile (P90-100) of the income distribution. However,

\footnotetext{
${ }^{20}$ It should be emphasized that the dynamic effects on capital accumulation, stressed in the literature on top incomes are not captured well in the econometric estimates (as the impact from these are cumulative). As we discuss the results below we will therefore combine our results with simulations to get a better sense of the order of magnitude over time.

${ }^{21}$ Atkinson (2004) also point to taxes having ambiguous effects in "tournament theory" (Lazear and Rosen, 1981) where an increased tax decreases the return of advancement to the next level but also reduces the risk of attempting such advancement, and in the "winner-take-all" context considered in Frank (2000) where progressive taxation reduces the expected returns of entry. See Atkinson (2004) pages 135-138.

${ }^{22} \mathrm{~A}$ more detailed source description and more facts about the data can be found in a web appendix on the authors' web pages.
} 
recent studies following Piketty (2001) have shown that the top decile is very heterogeneous. ${ }^{23}$ For example, the income share of the bottom nine percentiles of the top decile (P90-99) has been remarkably stable over the past century in contrast to the share of the top percentile (P99-100), which fluctuated considerably. Moreover, while labor incomes dominate in the lower group of the top decile, capital incomes are relatively more important to the top percentile. In order to analyze the determinants of top income shares in detail we will differentiate between these groups of income earners within the top decile.

Based on the work of several researchers following the methodology first outlined in Piketty (2001), we have constructed a new panel dataset over top income shares for 16 countries covering most of the twentieth century. ${ }^{24}$ The main source is personal income tax returns, and income reported is typically gross total income, including labor, business and capital income (and in a few cases realized capital gains) before taxes and transfers. Top income shares are then computed by dividing the observed top incomes by the equivalent total income earned by the entire (tax) population, had everyone filed a personal tax return. In most countries only a minority of the people filed taxes before World War II and the computation of reference totals for income regularly include both tax statistics and various estimates from the national accounts. For this reason the reference total income is likely to be measured with some error. Despite the explicit efforts to make the series consistent and comparable there remain some known discrepancies in the data that are potentially problematic. ${ }^{25}$

We use three income variables to capture what we think are key aspects of the whole income distribution given the data limitations. Top1 (P99-100) measures the fraction of total income received by the percentile with the highest incomes, Top10-1 (P90-

\footnotetext{
${ }^{23}$ See Atkinson and Piketty (2007).

24 See the Table B2 in the Appendix for specific references and Atkinson and Piketty (2007) for details.

${ }^{25}$ Some differences in both income and income earner (tax unit) definitions remain. For example, realized capital gains are excluded from the income concept in all countries except for Australia, New Zealand and (partly) the UK. Tax unit definitions vary even more. In Argentina, Australia, Canada, China, India and Spain they are individuals but in Finland, France, Ireland, the Netherlands, Switzerland and the United States they are households (i.e., married couples or single individuals). Moreover, in Japan, New Zealand, Sweden and the United Kingdom the tax authorities switched from household to individual filing. In Germany there is a mixture of the two, with the majority of taxpayers being household tax units whereas the very rich filing as individuals. For a longer and more detailed discussion of these problems, see Atkinson and Piketty (2007, ch. 13).
} 
99) is the share received by the next nine percentiles, and Bot90 (P0-90) is the residual share received by the lowest ninety percent of the population. As already mentioned we think there are good reasons to approximate the rich by Top1, in that their income share is of a different makeup in terms of sources compared to the rest of the population and also shows considerable variation over time. Similarly it is fair to describe Top10-1 as the upper middle class since this group, with remarkable consistency across countries and over time, has been composed of mainly (highly) salaried wage earners. In fact, when examining the share of capital income of total income for these two top income groups in Canada, France, Sweden and the U.S. over the twentieth century, there is not a single point in time when the rich has lower capital income shares than the upper middle class. ${ }^{26}$ Finally, Bot90 consists clearly not of a homogenous group of income earners. Nonetheless this group, by construction, captures the aggregate outcome for the rest of the population and, as we will show, there seem to be some clear patterns of outcomes for "the top" and "the rest" of the population.

Beside the measures of shares out of total income we also use some measures of inequality within the top of the distribution. Specifically we use Top1/10, defined as the share of the top percentile in relation to the top decile, i.e., P99-100/P90-99, as well as Top01/1, the top 0.1 percentile income share divided by the rest of the top percentile's income share, P99.9-100/P99-99.9. These measures serve two purposes. First, they measure the inequality within the top of the distribution, which is different from inequality overall especially when considering theories that predict a widening gap among high income earners. Second, these measures are not sensitive to measurement error in the reference total income mentioned above. ${ }^{27}$

Financial development. The challenge in estimating financial sector development over the whole twentieth century is to find variables that are available and comparable for

\footnotetext{
${ }^{26}$ The average capital income shares between 1920 and 2000 in these four countries are about 6 percent for the upper middle class and about 19 percent for the rich Hence, although this division is as artificial as the classical distinction between workers and capitalists and it is likely that the precise division between the rich (whatever one means by this term) and the upper middle class is different across time and between countries. Nevertheless, the results from the top income literature indicate a surprisingly stable relation in that at least the lower half of the top decile is very different from the top percentile. We therefore use this terminology hoping that it invokes key distinctions between the very top and the group just below.

${ }_{27}$ To see this in the case of Top1/10, note that P99-100 $=\mathrm{Inc}_{\mathrm{Top} 1} / \mathrm{Inc}_{\mathrm{All}}$ and P90-100 $=\mathrm{Inc}_{\mathrm{Top} 10} / \mathrm{Inc}_{\mathrm{All}}$, which means that Top1/10 $=\left(\operatorname{Inc}_{\mathrm{Top} 1} / \operatorname{Inc}_{\mathrm{All}}\right) /\left(\operatorname{Inc}_{\mathrm{Top} 10} / \operatorname{Inc}_{\mathrm{All}}-\operatorname{Inc}_{\mathrm{Top} 1} / \operatorname{Inc}_{\mathrm{All}}\right)=\operatorname{Inc}_{\mathrm{Top} 1} /\left(\operatorname{Inc}_{\mathrm{Top} 10}-\operatorname{Inc}_{\mathrm{Top} 1}\right)$.
} 
all countries for such a long period. We use three different measures aimed at capturing the relative importance of private external finance: Bank deposits (deposits at private commercial and savings banks divided by GDP), Stock market capitalization (the market value of listed stocks and corporate bonds divided by GDP), and Total market capitalization (the sum of the first two, which is also our preferred measure). The variable Bank deposits closely matches private credit in the economy. ${ }^{28}$ By using these three different measures, we are also able to address possible distributional differences between bank-based and market-based financial development.

Our sources for bank deposits are Mitchell (1995, 1998a, 1998b) for the pre-1950 period and International Financial Statistics (IFS) and Financial Structure Database (FSD) for the post-1950 period. Data on stock market capitalization before 1975 come from Rajan and Zingales (2003), who present data for the years 1913, 1929, 1938, 1950, 1960 and 1970. We linearly interpolate between these years to get 5-year averages except for over the world wars as we deem such interpolated values to be highly uncertain. For this reason, the world wars are left out from most of our regressions. We then link these series with post-1975 data from FSD. One problem with the stock market capitalization measure is its potentially close connection to our income measure, which includes capital income (although not realized capital gains), i.e., returns on stocks and bonds. Hence, there could be a mechanical relation between top income shares and financial development if, for example, dividends tend to be high when stock market capitalization is high. This potential problem is, however, considerably smaller in the case of bank deposits, which hence also serves as a robustness check on the market capitalization results.

Openness. Our main measure of trade openness is a standard de facto measure: the sum of exports and imports as a share of GDP. For the pre-1960 period data come from Mitchell (1995, 1998a, 1998b), Rousseau and Sylla (2003) and López-Córdoba and Meissner (2005) and for the post-1960 period we use data from IFS. Data are generally lacking for wartime years. An alternative way to measure openness is to use rules-based measures. We use data on average tariffs, sum of paid tariffs over imports,

\footnotetext{
${ }^{28}$ We use bank deposits instead of private credit since we have much longer series of deposit data. For the country-years when the two measures overlap, however, the correlation is high (0.82). When replacing bank deposits with private credit in postwar regressions, moreover, the main results are qualitatively identical in both cases though somewhat weaker when using private credit.
} 
from Clemens and Williamson (2007) which is the only de jure measure with acceptable time-space coverage that we are aware of. Still, average tariffs is a quite problematic measure of trade openness for several reasons, e.g., by not capturing the variation in tariff rates and import values across different goods and also since a zero average tariff could reflect both complete openness (tariff rates are zero) or complete autarchy (tariff rates are so high that imports are zero). For this reason, we only use it for sensitivity purposes.

Central government spending. In order to account for the activity and growth of government over the period, we include a measure of Central government spending, defined as central government expenditure as a share of GDP. Data are from Rousseau and Sylla (2003). Ideally we would have liked to include both central and local governments since the spending patterns at these two administrative levels may both vary systematically across countries and within countries over time. For example, Swedish municipalities and counties have gradually taken over the state's responsibility for the provision of traditional public sector goods such as health care and schooling, thereby potentially causing a decrease in central government spending but not in total government spending. However, lacking a measure of total government spending, we think that our chosen alternative is the best available measure for capturing the growth of government over time. ${ }^{29}$

Top marginal tax rate. We use two measures of top marginal tax rates. Our first measure, called Margtax1, combines data on the statutory top marginal tax rates with some newly created series of marginal tax rates paid by those with incomes equal to five times GDP per capita, an income level approximately equal to the 99th income percentile. The reason for not only using statutory top rates is that these rates have been binding to quite varying degrees on top income across countries as well as within countries over time. ${ }^{30}$ New series with actual marginal tax rates paid are avail-

\footnotetext{
${ }^{29}$ Rousseau and Sylla (2003) use this variable in their study of the determinants of economic growth in an historical context. Central government spending to GDP is also the variable that is available in databases such as the Penn World Tables, the World Bank's World Development Indicators, and the IMF:s International Financial Statistics.

${ }^{30}$ For example, Roine and Waldenström (2009) shows for Sweden that over the entire century the top income percentile only paid a marginal tax rate equal to the statutory top rate in the years around 1980 . More generally, the statutory top rates have been relatively more binding to larger groups of income earners in Scandinavia and the U.K than in, e.g., Japan or the U.S.
} 
able thanks to previous efforts by Bach, Corneo and Steiner (2005) for Germany (since 1958), Roine and Waldenström (2009) for Sweden (whole period), and Rydqvist, Spizman and Strebulaev (2007) for Canada, the UK, and the US (postwar period). These series were calculated from national tax schedules for each of the countries. Our second measure of marginal tax rates, Margtax2, consists simply of the full set of statutory rates from all countries for which such data are available.

GDP per capita and Population size. For the variables GDP per capita and Population size we use data from Maddison (2006). ${ }^{31}$

\section{A first look at the data}

To get a sense of the relationships between our variables of interest it is useful to just look at the trends over time. After all, when it comes to some of the main findings in the individual country studies on top incomes, such as the effects of the Great Depression and World War II, these are apparent just from looking at the data. Figure 1 shows the development of our main dependent variable, the income share of the top percentile group (Top1) over the twentieth century for all countries in our sample.

Besides clearly showing the impact of the depression and World War II for many countries, another striking feature of the series is the strong common trend. With the exception of a few countries the development is remarkably similar over time, at least until around 1980. The same is, in varying degree, true for the main right-hand-side variables (at least for the development of GDP/capita, top marginal tax rates and central government spending). The panels in Figure 2 show the development of these since 1900 .

These signs of interdependencies are perhaps not so surprising given our focus on economies that have been relatively closely interconnected through events such as the Great Depression affecting top incomes in many of these countries in similar ways. One may also think of broad policies (taxation, liberalization, etc.) or changes in technology (financial innovation, factor flows, etc.) as being reflected in common trends

\footnotetext{
${ }^{31}$ When computing GDP shares for financial development and trade volumes, however, we use nominal GDP series in Bordo et al. (2001), Mitchell (1995, 1998a, 1998b) and Rousseau and Sylla (2003).
} 
of top income shares across countries. In the extreme this could be a problem for our econometric approach since we rely on within country changes in the relevant variables to identify effects, holding common trends constant. If there are changes across time in the explanatory variables but these are exactly the same everywhere, we would not find any effect even if there may be a relation. In other words, by taking out common trends, we run the risk of falsely rejecting a hypothesis because the patterns are too similar across countries. However, since no two countries are affected in exactly the same way by the developments throughout the 20th century, there should be enough variation in the data to disentangle the effects (see section 5 below). This problem is not unique to our study; exploiting the residual variation after having controlled for common effects is the standard way of approaching cross-country data.

Can we by just looking at the data find any clear patterns between the top income shares and the proposed explanatory variables over time? The short answer would have to be "no". As can be seen in Figure 2 the level of financial development is quite volatile up until the middle of the postwar period when it starts to increase. Trade openness, on the other hand, exhibits a more monotonic increase (except for the drastic drop in the Netherlands during World War I), and a similar pattern goes for GDP per capita. Government spending is increasing in all countries, with the well-known war-related spike in the 1940s. Top marginal taxation increases before World War II, but continues to be high throughout the postwar period up to its peak around 1980 when it mostly starts to decrease. Overall, there are no obvious links between any of these variables and the top income shares, although there is quite notable crosscountry variation to use in a more sophisticated analysis of the panel. Piketty (2005) and Piketty and Saez (2006) make a similar simple eyeballing exercise to provide some suggestive evidence on the inequality-growth links, but in the end conclude that using all countries in the database might produce more convincing results and renew the analysis of the interplay between inequality and growth. The natural next step, therefore, is to study these relationships more rigorously.

\section{Panel estimations: Econometric method}

The theoretical discussion concerning the potential determinants of top income shares is suggestive, but inconclusive. Financial development has been suggested to increase 
as well as to decrease top income shares and the same goes for trade openness and the effect of economic growth. Even if theory on the effect on taxation is ambiguous, we do, however, expect to find that a larger government and higher tax rates (especially higher top marginal taxes) are associated with lower top income shares. ${ }^{32}$ When it comes to finding possible relations between variables based on simply eye-balling the time series, we have concluded that there are no obvious links to be suggested. We therefore proceed with panel estimates of the effects on these variables on top income shares. Panel estimations allow us to take all unobservable time-invariant factors into account. Further, it allows us to control for both common and country specific trends. Thus, we can test for specific hypotheses regarding the relation between different variables on top income shares.

When estimating the determinants of top income shares using a long and narrow panel of countries, the assumptions underlying the standard fixed effects model are likely to be violated. In particular, serial correlation in the error terms can be expected. We therefore apply the less demanding first difference estimator which relies on the assumption that the first differences of the error terms are serially uncorrelated. As annual data can be quite noisy in a first-differenced setting, we use 5-year averages of the data rather than annual values. Assuming a linear relationship between the variables of interest, this means that we start by estimating the following regression:

$$
\Delta y_{i t}=\Delta \mathbf{X}_{\mathrm{it}}^{\prime} b_{1}+\gamma_{t}+\mu_{i}+\varepsilon_{i t}
$$

This is a standard first difference regression including fixed time effects $\gamma_{t}$ and country specific trends (here captured by a country specific effect $\mu_{i}$ ). Further, $\Delta \mathbf{X}_{\mathbf{i t}}$ is the vector of (first-differenced) variables that we are interested in as well as other control variables. Of course, the assumption of no serial correlation in the error terms does not necessarily hold, even after first-differencing. Indeed, some preliminary tests suggest that serial correlation is a problem in this setting. ${ }^{33}$ To account for serial correla-

\footnotetext{
${ }^{32}$ This is partly assuming that disincentive effects dominate, but also based on the potential dynamic effects on capital accumulation. Some of the individual country studies on top incomes have also found that higher marginal taxes have indeed lowered top income shares.

${ }^{33}$ The test procedure follows Wooldridge (2002, Chapter 10.6): We run regression (1) and keep the residuals. We then rerun the regression and include the lagged residuals in the estimation. Since the
} 
tion, we follow two different strategies. Our main approach is to estimate (1) using GLS and directly allow for country specific serial correlation in the error terms. The assumption of a linear relationship is by no means innocuous, especially considering the long time-frame of our study. A important part of our study therefore analyses potential non-linearities in the data. For example, we analyze if various effects differ across different levels of economic development. ${ }^{34}$

As an alternative approach, one could include the lagged dependent variable, thereby explicitly allowing for the dynamics that give rise to serial correlation. This means that we estimate the following regression:

$$
\Delta y_{i t}=b_{0} \Delta y_{i t-1}+\Delta \mathbf{X}_{\mathrm{it}}^{\prime} b_{1}+\gamma_{t}+\mu_{i}+\varepsilon_{i t}
$$

Applying the same test as above shows that serial correlation is no longer a problem when using a dynamic specification. However, the inclusion of the lagged dependent variable is not unproblematic since it is correlated with the unobserved fixed effects. Thereby, we could get biased estimates. This bias is reduced when $T$ is large (Nickell, 1981). $T$ does in this case depend on the actual time horizon on which the data is based. In other words, in our case where $T$ is 100 years, the bias is not likely to be a major problem even if we only use 20 periods based on 5-year averages. Furthermore, the standard way of dealing with the dynamic panel data problem is to use GMMprocedures along the lines of Arellano and Bond (1991) or Arellano and Bover (1995). ${ }^{35}$ But these GMM-procedures are not appropriate in a setting with small $N$ and large $T$ such as ours (Roodman, 2007). For these reasons we run regression (2) without any adjustments or instrumentation. Both when using dynamic first differences and first differenced GLS, we allow for heteroskedasticity in the error terms. In order to limit the number of tables, we only report the GLS results in the main paper, but all regressions are also run using the first difference approach.

\footnotetext{
coefficient on the lagged residual is positive and significant, we can conclude that serial correlation is a problem even after taking first differences.

${ }^{34}$ Another issue is that our dependent variable is bounded between 1 and 100 . In practice, this is likely to be a minor concern as the top income share is never close to these extreme values. Linearizing the dependent variable using the transformation $y=\ln$ (top income share/(100-top income share)) matters little for the results.

${ }^{35}$ Lagged levels and differences of the endogenous variable/s are used as instruments in these GMMprocedures.
} 
The fact that we control for trends and time invariant country factors does not mean that we have fully addressed potential endogeneity problems. First of all, we could have direct reverse causality from top income shares to our explanatory variables. This would be the case if, for example, top income shares would have a direct effect on economic growth, rather than the other way around. Similarly, high top income shares could affect financial development positively if individuals in the top of the income distribution are relatively prone to make use of the financial markets for saving and investment. It is more difficult to see a problem of reverse causality from top incomes to trade and government spending, but a high income concentration can of course affect the political trade-offs facing a government. This, in turn, can affect trade policies, government spending and how the tax system is structured. Second, it is possible that some uncontrolled factor affects both top income shares and the respective control variables. This would then give rise to an omitted variable bias of our estimates.

The ideal way of dealing with these endogeneity problems is to find some credible instrument for each respective explanatory variable. Since our approach here is to take an agnostic view on several potential explanations for top incomes over a long period, instrumentation is not feasible for all variables. However, when estimating the impact of internationalization we will rely on both de facto and de jure measures of openness. In order to get at the impact of financial development, we will both use direct measures and analyze the effects of banking crises on top income shares. Neither of these approaches is ideal so we cannot claim to fully establish causality. Despite these shortcomings we regard our contribution as being a first systematic take on the various explanations of top income shares that have been proposed in the literature.

\section{Results}

In this section, we report the results from panel regressions using the above estimation methods. Throughout, we have used both first differenced GLS (FDGLS) and dynamic first differences (DFD), but as these give very similar results we only display the FDGLS results in our main tables while showing the DFD output in Appendix B. ${ }^{36}$

\footnotetext{
${ }^{36}$ We choose to present the results from FDGLS because it deals more directly with serially correlated errors.
} 
In all tables showing the results, the dependent variables are the five different income shares presented in the data section: the top percentile (Top1), the next nine percentiles in the top decile (Top10-1), the bottom nine deciles (Bot90), the top percentile divided by the rest of the top decile (Top1/10) and, finally, the top 0.1 percentile divided by the rest of the top percentile (Top01/1). As has already been stated, the results are not sensitive to altering the exact percentile limits between these income earner groups. $^{37}$

The presentation of the results starts by looking at average long-run effects over the whole income distribution. We then allow for: different effects across levels of development, differences between Anglo-Saxon and other countries and differences between bank- and market-oriented financial systems. Thereafter we show that our results are robust to restricting the sample in a number of ways as well to using alternative marginal tax measures. ${ }^{38}$

\subsection{Main results}

Table 5 presents the results from our baseline FDGLS regressions. The explanatory variables in all regressions are growth in GDP per capita, financial development (as measured by total capitalization), population size, central government spending, and openness to trade. The difference between odd and even numbered columns is that the latter also includes top marginal tax rates.

A number of clear and interesting results are shown in Table 5. First, there is a strong positive relation between GDP per capita growth and the changes in the top income share. The regression coefficients for Top1, Top1/10 and Top01/1 are all significantly positive suggesting that in periods of high growth the rich have benefitted more than proportionately over the entire twentieth century. Furthermore this relationship is stronger the higher up the distribution one gets. In sharp contrast to those results is the

\footnotetext{
${ }^{37}$ Using all possible variants of top income share groups that are available to us from the different country case studies, we find no important variation in our results (available upon request). For example, we try splitting the rich in Top1 (P99-100) into two halves (P99-99.5 and P99.5-100) and, similarly, redefining the upper middle class as the next four percent (P95-99) in the top decile instead of the next nine percent (P90-99), finding qualitatively identical results.

${ }^{38}$ Judging from the descriptive analysis of Section 3, it is obvious that the two world wars had an impact on top income shares. As we lack data on several variables for the war years they are excluded from the empirical analysis. Even if data had been available, it would have been difficult to separate different explanations during periods of such dramatic changes as the war years.
} 
negative relationship between growth and changes in the income share for the next nine percentiles in the top decile, Top10-1, which we think of as the upper middle class group. The most plausible explanation for this finding is perhaps simply that the top percentile group has a larger share of their income tied to the actual development of the economy, while the following nine, as pointed out in much of the top income literature, are mainly highly salaried workers but with relatively limited bonus programs, stock options, and other performance related payments. As shown in the above section describing the income data, their capital income share is also significantly lower than that of the rich. The unclear result for the rest of the population is likely to reflect the heterogeneous experiences within this group. Quantitatively the estimated effects suggest that an average growth rate of 10 percent, which seems reasonable over a five year period, increases the income share of the top percentile by about 0.6 percentage points (the mean of Top1 is 10.6). As for the effects within top income earner, columns 7 and 8 shows an increase of approximately 0.03 (the mean of Top1/10 is 0.45$)$.

Financial development also turns out to have been pro-rich over the past century, with increases in total capitalization being significantly associated with increases in the top income percentile. Unlike the growth effects, however, the effect for the following nine percentiles is statistically insignificant, while the effect on the nine lowest deciles seems to be negative (although with varying degree of statistical certainty). It is not trivial to gauge the size of the estimated effects, but the following exercise can be useful. Increasing total capitalization by one standard deviation $(0.5$, or 50 percent of GDP), is related to an increase in income share of the top percentile by about 0.5 percentage points. As the mean income share of this group is about 10 percent, this effect is quite small. If we instead use the estimates from within the top decile (columns 7 and 8), we see that the same increase in is related to an increase in the income share of the top percentile by about 0.15 . As the top percentile on average has an income share of 0.45 of the Top10-1 group, this effect must be considered very large. In other words, financial development has large redistributive consequences within the group of high-income earners, but the consequences for the overall distribution of income are more limited. 
Looking at the role of the state, the effects on inequality are in line with what one might expect. Central government expenditures increases the income share of the nine lowest deciles, decreases the share of the upper middle class group, but has no significant effect on the top percentile. Increasing central government spending by one standard deviation (about 0.07) is related to a reduction in the income share of the upper middle class by about 1.6 percentage points (the average income share of this group is about 23 percent). The most surprising finding regarding the amount of government spending is that the highest income earners appear to be unaffected.

Furthermore, top marginal taxes have a negative effect on the whole top group, both the top percentile and the following nine percentiles, while the effect for the lower nine deciles is strongly positive. As our income shares are pre-tax this suggests that high marginal tax rates have an equalizing effect beyond the direct impact of taxation, something which is not theoretically obvious. ${ }^{39}$ The direct effects of taxation are relatively small. Increasing top marginal taxes from 50 to 70 percent (approximately one standard deviation), reduces the income share of the top percentile by 0.86 percentage points. Within the top decile, the same increase in taxes leads to a reduction of the earnings of the top percentile by 0.03 which should be compared to the mean of 0.45 . However, when taking the cumulative effects of taxation into account may still be important in explaining changes in inequality.

Appendix B contains results from simple simulations of the dynamic effects under different assumptions about capital accumulation in response to tax increases and shocks to the capital stock (as well as their combined effect). ${ }^{40}$ Assuming that capital owners (overrepresented in the top of the distribution) use some of their capital to uphold consumption the tax increase will not only affect disposable income in the current period but also future (capital) income. Piketty and Saez (2006) argue that the tax increases in the 1940s and 1950s had precisely this type of effect when combined with the shocks to capital during World War II. Our stylized simulations show that tax increases in the order of magnitude that took place in many countries around the 1950s could indeed have important cumulative effects. For example, in response to a tax increase from 0.3 to 0.5 , the income share of the top percentile would decrease from 15

\footnotetext{
${ }^{39}$ See e.g., Atkinson (2004) and the discussion in Section 2 above.

${ }^{40}$ These simulations are very similar to those in Piketty (2001b).
} 
percent to 14.2 percent in five periods (assuming they uphold consumption by decreasing savings). After ten periods it would be 13.5 percent and after 15 periods 12.6 percent. When combined with a shock to capital the numbers would be 12.3, 11.2, and 9.9 percent after 5, 10, and 15 periods respectively. As illustrated in Appendix B changing the consumption response or altering the level of tax increase or capital shock does not alter the basic insight: Small short term effects - of the size that we find in our panel estimation - can be significant over time through their effect on capital accumulation.

Finally, contrary to what is often asserted openness, i.e., the trade to GDP-ratio, is not strongly related to top income shares at all. If anything the relationship is negative but when we use average tariff protection as measure of openness the coefficients for the rich are positive but insignificantly different from zero. ${ }^{41}$ As we include time fixed effects and thereby control for any general changes in globalization it is still possible that while "general globalization" increases income inequality country specific trade openness does not. However, the mechanism behind such a result would be quite difficult to spell out.

The issue of "general globalization" brings us to the question of how much of the variation in top income shares that can be explained by common time shocks and what the explanatory power of the time varying control variables is. As we noted in section 4 , one of the few things that can be said about the data just by looking at it is that there seems to be a strong common trend. It is therefore interesting to see exactly how much of variation that can be explained by this. Our estimates suggest that a full 35 percent of the variation in the first-differenced top income share can be explained by the time fixed effects. ${ }^{42}$ Adding the base set of controls explains another 7 percent, and the inclusion of country time trends adds another 12 percentage points of explanatory power. Hence, a substantial amount of the variation can be attributed to general changes in economic conditions.

\footnotetext{
${ }^{41}$ Results using average tariffs are available upon request.

42 The estimated coefficients for the time fixed effects in the main regressions are about zero before the 1980s. After that, however, they increase constantly, peaking during the 1995-2000 period.
} 


\subsection{Different effects depending on the level of economic development}

As discussed in section 2, the effect of several variables on top income shares could theoretically be expected to depend on the level of economic development. In this section, we analyze this possibility by splitting the sample into three similar sized groups based on per capita GDP. ${ }^{43}$ Thereafter we interact these groups with the respective variable of interest. Table 6 presents the results from this exercise.

Overall, there is little evidence that the effect of GDP growth on top incomes depends on the level of development. The point estimates have the same signs and levels of significance in almost all cases and F-tests of equal coefficients across development groups are mostly not rejected.

When it comes to the effect of financial development depending on the level of economic development, however, a more interesting variation is observed. According to the basic idea of Greenwood and Jovanovic (1990), financial development should benefit the rich in early stages of development, but then spread to benefit everyone as the economy becomes more developed. Our results seem to be in line with this idea; the very richest among the top income earners benefit more from financial development especially at low levels of development. Note that once again it seems to be primarily the rest of the top decile (P90-99) that loose out on this development.

We also analyzed the effects on inequality coming from trade openness and central government spending over the level of economic development but could not find any observable differences and therefore suppress these results in our tables.

\subsection{Banking crises and financial systems: A deeper look at the role of finance}

Among the strongest result so far is that financial development is highly positively related to top income shares. Establishing a causal relationship from financial development to top income shares would therefore be valuable. To this end we use the fact that banking crises cause drastic contractions of the financial sector. Using data from Bordo et al. (2001) and Laeven and Valencia (2008) on banking crises, we can esti-

\footnotetext{
${ }^{43}$ High income if GDP per capita is greater or equal to 15365 USD per year, middle income if GDP per capita is between 15365 and 9701 USD per year, and low income if GDP per capita is less than or equal to 9701 USD per year.
} 
mate the impact of these events on top income shares. When doing this, we naturally do not include any direct controls for financial development as these are endogenous to the crises itself. In the first column of Table 7, we see that the share of years during each 5-year time period that a country was exposed to a banking crises has a substantive negative impact on top income shares (results are similar when using a binary indicator for a crisis period).

One possibility is that this relation is due to some general crisis effect, rather than the banking crises per se. In the second column therefore, we include a similar variable representing periods during which currency crises occurred. As can be seen, however, these episodes do not have a significant impact on top incomes. In the next two columns, we see that neither type of crises had a significant impact on the income shares of the upper middle class. This is consistent with our original findings that the income shares of this group in unaffected by financial development.

In the literature on top income shares, the diverging pattern between Anglo-Saxon countries and continental Europe has been stressed. ${ }^{44}$ One possibility is that this is due to differences in the financial systems. While Anglo-Saxon countries tend to have stock market based financial systems, most of continental Europe and the rest of the world have relatively bank based financial systems (see, e.g., Boot and Thakor, 1997, Allen and Gale, 2000, and Levine, 2005). Hence, if there are differences between these systems in terms of allocating capital and generate returns to savings that would give rise to differences in the relative size of capital income and hence the development of income inequality across Anglo-Saxon and other countries.

In Table 8, we analyze this issue explicitly by breaking up our combined measure of financial development, total capitalization, into its components. In columns (1) and (4) we use Bank deposits and in columns (2) and (5) we use Stock market capitalization to measure financial development. The main findings in Table 8 show, however, that there are no systematic differences in distributional influences across the two types of financial systems. This does not only tell us that different types of financial

\footnotetext{
${ }^{44}$ This difference is one of the main findings in the recent research on top incomes. Indeed, the title of the recent volume edited by Anthony Atkinson and Thomas Piketty, collecting much of this work is Top Incomes over the Twentieth Century: A Contrast between European and English-Speaking Countries.
} 
development are unlikely to have a differential impact on top income shares. As bank deposits are much less affected by current market conditions than stock market capitalization, it these findings also reduce the likelihood that we capture a mechanical relationship between stock market capitalization and top incomes.

Finally, there are several different ways to proxy for financial development. We make use of bank deposits to capture the amount of credit in the economy. An alternative measure of this is the share of private credit to GDP. The two proxies are highly correlated and as can be seen in columns (3) and (6) the results are qualitatively similar regardless of which proxy we use.

In sum, the results for banking crises suggest a causal relationship between financial development and top income shares. Moreover, that the pattern is the same for bank based measures of financial development (bank deposits and private credit) and market based measures (stock market capitalization) means that this is not likely to be due to a mechanical relation between market capitalization and top income shares.

\subsection{Are Anglo-Saxon countries different?}

Based on the different developments from 1980 and onwards, it has been suggested that the evolution of top income shares in Anglo-Saxon countries differs from that of continental Europe. ${ }^{45}$ Empirically speaking, there are two possibilities: Anglo-Saxon countries may either have had a different development in the underlying determinants of top income shares, or the response of top incomes to the underlying determinants differs - for some reason - between the two groups of countries. In Table 9, we address this issue by interacting a dummy variable indicating that a country is AngloSaxon with the main variables of interest. ${ }^{46}$ We can then directly answer the question if the slope coefficients differ between Anglo-Saxon and other countries.

The results do not indicate any systematic distributional effects from either economic growth or trade openness that differ between the two country-groups. In a few cases the estimated coefficients are statistically significant, but they fail to provide a consis-

\footnotetext{
${ }^{45}$ See, e.g., Atkinson and Piketty (2007).

${ }^{46}$ Anglo-Saxon countries are Australia, Canada, New Zealand, the UK and the US.
} 
tent pattern. ${ }^{47}$ Another possibility that has been discussed in the literature is that the different groups of countries differ in their acceptance of inequality. ${ }^{48}$ One, admittedly quite weak, way to test this hypothesis is to analyze if government spending is relatively pro-rich in Anglo-Saxon countries. When we interact government expenditures with the Anglo-Saxon indicator the interaction term is, however, not statistically significant (suppressed in the table). We can therefore not see any indication that the distributional impact of government spending is different in the two country groups.

An alternative approach to the question of why Anglo-Saxon countries differ from continental Europe is to analyze the diverging time trends between the two groups of countries. Specifically, we ask if these differences are reduced when we include our set of control variables. In Figure 3, we graph the interaction terms between time fixed effects and an Anglo-Saxon dummy, with and without our base set of control variables. ${ }^{49}$ As should be clear, this exercise indicates that the difference between the two groups of countries is - if anything - more pronounced after we control observable characteristics. Thus, the difference between the two groups of countries must be due to other factors. Unfortunately, our data does not allow us to pursue the question further.

\subsection{Sample restrictions, extensions and robustness}

In Table 10, we conduct a set of robustness tests, based on sample restrictions and alternative measures used. First, we replace our de facto openness variable, Openness, by a de jure measure of openness, Tariffs. This change does not alter the findings and openness remains basically unimportant to explain long-run trends in income inequality. Second, we restrict the sample to the post World War II-period, dropping all observations prior to 1950 . The main reason for doing this is that the pre-war period includes the great depression era, during which the volatility of growth rates and changes in the income distribution were quite extreme. Further, top income shares declined rapidly during the Second World War, possibly for reasons unrelated to the

\footnotetext{
${ }^{47}$ See, e.g., the negative effects of openness and growth in Anglo-Saxon countries on both Bot90 and Top01/1 while at the same time Top1/10 in these countries is positively affected by openness.

${ }_{48} \mathrm{See}$, for example the discussion in Piketty and Saez (2005).

49 As the diverging patterns are main apparent from 1980 an onwards, we only display these results for the post WWII-period.
} 
economic forces we are analyzing. The main results are unchanged by this sample restriction. $^{50}$

Third, we replace the preferred marginal tax measure, Margtax1, by the alternative Margtax2, containing solely statutory top rates. The correlation between the two series 0.80 (in first differences), which is high. Table 10 also reports roughly the same negative relationship between marginal taxes and income inequality as we saw in our main results in Table 5. The coefficient sizes are somewhat lower and the standard errors larger. Overall, however, switching tax measure does not alter the conclusions drawn from our main analysis.

Fourth, other factors that may contribute to changes in income inequality are technological and democratic developments. We analyze the role of technology in two ways: as the share of agricultural production in GDP (Agrishare) and as the stock of domestic patents (Patents). As shown in Table 10, neither of these variables suggest technology to have a crucial long-run impact on inequality. Furthermore, we have also incorporated variables on democratic standards in countries and evaluated their impact on the long-run inequality trends. However, neither their main effects nor their interaction the other explanatory variables appear to have any significant effects. ${ }^{51}$

\section{Conclusions}

This paper set out to empirically analyze the long-run relationships between top income shares and financial development, trade openness, the size of government, and economic growth. While these relationships, of course, have been extensively studied before, the unique contribution of this paper lies in the long time period for which we have data. Combining findings from a number of recent studies on top incomes with other historical data, our results are based on developments over the whole of the twentieth century. Using a panel data approach allows us to take all unobservable time-invariant factors, as well as country specific trends into account.

\footnotetext{
${ }^{50} \mathrm{We}$ also try dropping Japan from the sample as we lacked data on the top income decile for Japan, which affects our computed income shares for both the upper middle class and the rest of the population. This exclusion has no effect on our results..

${ }^{51}$ We use data on democracy from the Polity IV dataset. The lack of significant results (which are available upon request) is most likely due to the low within-country variation of this variables during the major part of our study period.
} 
Two findings stand out as being significant and robust across all specifications. First, economic growth seems to have been pro-rich over the twentieth century. More precisely, in periods when a country has grown faster than average, top income earners have benefited more than proportionally. A likely reason for this result is simply that, top incomes are (and have been) more closely related to actual performance than incomes on average. This result is similar at different levels of development and is not different between Anglo-Saxon and other countries. Second, we also find financial development to have been pro-rich over the twentieth century. This effect is also similar in Anglo-Saxon countries and elsewhere, it does not depend on whether financial development is approximated using bank deposits or stock market capitalization (often said to be a difference between Continental Europe and Anglo-Saxon countries), but it seems to depend on the degree of economic development. In line with the model in Greenwood and Jovanovic (1990) we find that the effect is strongest at relatively low levels of economic development. Furthermore, to explore in more detail how financial development might be pro-rich we have also studied the effects of banking and currency crises and find that only banking crises have had a significant negative impact on top income shares.

Regarding the much debated distributional effects of trade openness we do not find any evidence of this being disproportionately beneficial for top income earners on average. If anything the relationship is negative in some specifications. However, here there is a difference across groups of countries. Increased trade is associated with increased top incomes in Anglo-Saxon countries; but not in continental Europe. The difference is large enough to explain a substantial part of the different development of top incomes in the two country groups since 1980 . While we can only speculate about the causes behind these different responses to trade, it is possible that labor market institutions might play a role. ${ }^{52}$

Finally, when it comes to government spending and top marginal tax rates these seem to have been equalizing as increases in both these variables are associated with dis-

\footnotetext{
${ }^{52}$ As has been documented by Botero et al (2004), countries of English legal origin have weaker employment protection, weaker trade unions, and weaker social security laws. All of these can affect the impact of trade on the distribution of income.
} 
proportionate gains for the nine lowest deciles. Higher marginal tax rates have been negative for both the rich and the upper middle class, but interestingly government spending seems to have been neutral for the top but negative for the next nine percentiles. It is also worth emphasizing that as our inequality measures are pre-tax, the results capture effects over and above the direct impact of taxation and transfers. Quantitatively the short term effects of high marginal taxes are small but when placed in a dynamic context, especially when combined with shocks to capital, the effects quickly add up to potentially explaining much of the observed equalization after the Second World War.

Needless to say, a paper with a scope such as this leaves many stones unturned. For example, it is likely that the distributional impact of income shocks differ substantially, depending both on the nature of the shock and the institutional set-up of a particular country. We hope that our work will stimulate detailed research on such particularities. Such research would greatly improve our understanding of the drivers of income inequality. 


\section{References}

Aghion, Philippe and Patrick Bolton (1997), "A Theory of Trickle-Down Growth and Development”, Review of Economic Studies, 64, 151-172.

Allen, Franklin and Douglas Gale (2000), Comparing Financial Systems, Cambridge, MA: MIT Press

Alvaredo, Facundo (2009), "The Rich in Argentina over the Twentieth Century: 1932-2004", in A.B. Atkinson and T. Piketty (eds.), Top Incomes: A Global Perspective. Volume II, Oxford: Oxford University Press.

Andrews, Dan, Jencks, Christopher, and Andrew Leigh (2008), "Do Rising Top Incomes Lift All Boats?", mimeo, Harvard University.

Arellano, M. and S. Bond (1991), "Some Tests of Specification for Panel Data: Monte Carlo Evidence and an Application to Employment Equations", Review of Economic Studies, 58, 277-298.

Arellano, M. and O. Bover (1995), “Another Look at Instrumental Variables Estimation of Error Components Models", Journal of Econometrics 68(), 29-51.

Atkinson, Anthony B. (2004), "Income Tax and Top Incomes over the Twentieth Century”, Revista de Economía Pública, 168(1/2004): 123-141

Atkinson, Anthony B. and Andrew Leigh (2007a), "The Distribution of Top Incomes in Australia", in Atkinson, Anthony B. and Thomas Piketty (eds.), Top Incomes over the Twentieth Century: A Contrast between European and EnglishSpeaking Countries, Oxford: Oxford University Press.

Atkinson, Anthony B. and Andrew Leigh (2007b), "The Distribution of Top Incomes in New Zealand", in Atkinson, Anthony B. and Thomas Piketty (eds.), Top Incomes over the Twentieth Century: A Contrast between European and EnglishSpeaking Countries, Oxford: Oxford University Press.

Atkinson, Anthony B. and Andrew Leigh (2007c), "The Distribution of Top Incomes in Five Anglo-Saxon Countries over the Twentieth Century", mimeo, Australian National University.

Atkinson, Anthony B. and Thomas Piketty (eds.) (2007), Top Incomes over the Twentieth Century: A Contrast between European and English-Speaking Countries, Oxford: Oxford University Press.

Atkinson, Anthony B. and Thomas Piketty (eds.) (2009), Top Incomes: A Global Perspective. Volume II, Oxford: Oxford University Press.

Bach, Stefan, Giacomo Corneo and Victor Steiner (2005), “Top Incomes and Top Taxes in Germany", mimeo, DIW Berlin. 
Banerjee, Abihit and Thomas Piketty (2009), "Top Indian Incomes, 1922-2000”, in A.B. Atkinson and T. Piketty (eds.), Top Incomes: A Global Perspective. Volume II, Oxford: Oxford University Press.

Bardhan, Pranab, Bowles, Samuel, and Michael Wallerstein, (eds.) (2006), Globalization and Egalitarian Redistribution, New York: Russell Sage Foundation, and Princeton and Oxford; Princeton University Press.

Beck, Thorsten, Asli Demirgüç-Kunt and Ross Levine (2007), "Finance, Inequality and the Poor", Journal of Economic Growth 12(1), 27-49.

Bordo, Michael, Barry Eichengreen, Daniela Klingebiel and Maria Soledad MartinezPeria, (2001), "Is the Crisis Problem Growing More Severe?", Economic Policy 16(32).

Bordo, Michael D., Alan M. Taylor, and Jeffrey G. Williamson (eds) (2005), Globalization in Historical Perspective, Chicago: University of Chicago Press.

Botero, Juan C., Simeon Djankov, Rafael La Porta, Florencio Lopez-de-Silanes and Andrei Shleifer (2004), “The Regulation of Labor", Quarterly Journal of Economics 119(4), 1339-1382.

Boot, Arnoud W.A. and Anjan V. Thakor (1997), "Financial System Architecture", Review of Financial Studies 10(3), 693-733.

Bourguignon, Francois, and Christian Morrison (2002), "Inequality among World citizens: 1820-1992”, American Economic Review 92(4):727-744.

Claessens, Stijn and Enrico Perotti (2005), "The Links between Finance and Inequality: Channels and Evidence", background paper to the World Development Report 2006, World Bank.

Clemens, Michael A. and Jeffrey G. Williamson (2004), "Why Did the Tariff-Growth Correlation Change after 1950?” Journal of Economic Growth 9(1): 5-46.

Cline, William R. (1997) “Trade and Income Distribution”, Washington, D.C.: Institute for International Economics.

Cornia, Giovanni A. (2003) "The Impact of Liberalization and Globalization On Within-Country Income Inequality”, CESifo Economic Studies, 49(4), 581-616.

Dell, Fabien (2007), "Top Incomes in Germany throughout the Twentieth Century", in Atkinson, Anthony B. and Thomas Piketty (eds.), Top Incomes over the Twentieth Century: A Contrast between European and English-Speaking Countries, Oxford: Oxford University Press.

Dell, Fabien, Thomas Piketty and Emmanuel Saez (2007), "Income and Wealth Concentration in Switzerland over the Twentieth Century", in Atkinson, Anthony B. and Thomas Piketty (eds.), Top Incomes over the Twentieth Century: A Contrast between European and English-Speaking Countries, Oxford: Oxford University Press. 
Dew-Becker, Ian and Robert J. Gordon (2005) "Where Did the Productivity Growth Go? Inflation Dynamics and the Distribution of Income", Brooking Papers on Economic Activity, 2, 67-127

Easterly, William (2005) "National Policies and Economic Growth", in Philippe Aghion and Steven Durlauf (eds.), Handbook of Economic Growth, Elsevier

Financial Structure Database (FSD) (2006), updated version of Beck, Thorsten, Asli Demirgüç-Kunt and Ross Levine, (2000), "A New Database on Financial Development and Structure”, World Bank Economic Review 14, 597-605.

Frank, Robert H. (2000), "Progressive Taxation and the Incentive Problem", in J. B. Slemrod, editor, Does Atlas Shrug?, New York: Russell Sage Foundation.

Gabaix, Xavier and Augustin Landier (2007), "Why Has CEO Pay Increased So Much?”, Quarterly Journal of Economics forthcoming.

Galor, Oded and Joseph Zeira (1993), "Income Distribution and Macroeconomics", Review of Economic Studies, 60, 35-52.

Gersbach, Hans and Armin Schmutzler (2007), "Does Globalization Create Superstars?", CEPR Discussion Papers 6222.

Greenwood, Jeremy and Boyan Jovanovic (1990), "Financial Development, Growth and the Income Distribution", Journal of Political Economy 98, 1076-1107.

Harrison, Ann (ed.) (2006), Globalization and Poverty, Chicago: University of Chicago Press.

Hoffman, Philip T., Postel-Vinay, Gilles, and Jean-Laurent Rosenthal (2007), Surviving large losses: Financial Crises, The Middle Class, And The Development Of Capital Markets. Cambridge, (MA): Harvard University Press.

International Financial Statistics (IFS), International Monetary Fond.

IMF (2007), World Economic Outlook 2007. Globalization and Inequality. Washington DC: IMF.

Jäntti, Markus, Marja, Riihelä, Risto Sullström and Matti Tuomala (2009), "Trends in Top Income Shares in Finland”, in A.B. Atkinson and T. Piketty (eds.) (2009), Top Incomes: A Global Perspective. Volume II, Oxford: Oxford University Press.

Kaplan, Steven and Joshua Rauh (2007), "Wall Street and Main Street: What Contributes to the Rise in the Highest Incomes?", NBER WP \# 13270.

Laeven, Luc and Fabian Valencia (2008), "Systemic Banking Crises: A New Database", IMF WP 08/224.

Lazear, Edward P. and Sherwin Rosen (1981), "Rank-order Tournaments as Optimum Labor Contracts", Journal of Political Economy, 89: 841-864. 
Levine, Ross (2005), "Finance and Growth: Theory and Evidence." in Philippe Aghion and Steven Durlauf (eds.) Handbook of Economic Growth, The Netherlands: Elsevier Science.

López-Córdova, J. Ernesto and Christopher M. Meissner (2005), "The Globalization of Trade and Democracy, 1870-2000”, NBER WP \# 11117.

Maddison, Angus (2006), "World Population, GDP and Per Capita GDP, 1-2003 AD”, Excel file at http://www.ggdc.net/maddison/ (2006-11-30).

Madsen, Jakob (2007), "Technology spillover through trade and TFP convergence: 135 years of evidence for the OECD countries", Journal of International Economics 72(2), 464-480.

Manasse, Paolo and Alessandro Turrini (2001) "Trade, Wages, and 'Superstars", Journal of International Economics 54(1), 97-117,

Mitchell, Brian R. (1995), International Historical Statistics: Africa, Asia \& Oceania 1750-1988, Basingstoke: Macmillan

Mitchell, Brian R. (1998a), International Historical Statistics: Europe 1750-1993, Basingstoke: Macmillan

Mitchell, Brian R. (1998b), International Historical Statistics: the Americas 17501993, Basingstoke: Macmillan.

Mookherjee, Dilip, and Debraj Ray (2006). "Occupational Diversity and Endogenous Inequality", mimeo, Boston University and New York University: Boston and New York

Moriguchi, Chiaki and Emmanuel Saez (2009), "The Evolution of Income Concentration in Japan, 1885-2005: Evidence from Income Tax Statistics", in A.B. Atkinson and T. Piketty (eds.) (2009), Top Incomes: A Global Perspective. Volume II, Oxford: Oxford University Press.

Nickell, Stephen (1981), "Biases in Dynamic Models with Fixed Effects", Econometrica, 1399-1416.

Nolan, Brian (2007), "Long Term Trends in Top Income Shares in Ireland", in Atkinson, Anthony B. and Thomas Piketty (eds.), Top Incomes over the Twentieth Century: A Contrast between European and English-Speaking Countries, Oxford: Oxford University Press.

O'Rourke, Kevin H. (2001) "Globalization and Inequality: Historical Trends," Annual World Bank Conference on Development Economics (2001/2), pp. 39-67.

O’Rourke, Kevin H. and Jeffrey G. Williamson (2002), “After Columbus: Explaining the Global Trade Boom 1500-1800", Journal of Economic History 62(2), 417456

Perotti, Enrico C. and Volpin, Paolo F. (2004), "Lobbying on Entry”, CEPR Discussion Paper No. 4519. 
Piketty, Thomas (2001), Les hauts revenus en France au 20ème siècle, Grasset, Paris.

Piketty, Thomas (2001b), "Income Inequality in France, 1900-1998”, CEPR Discussion Paper No. 2876.

Piketty, Thomas (2007), "Income Inequality in France, 1900-1998”, in Atkinson, Anthony B. and Thomas Piketty (eds.), Top Incomes over the Twentieth Century: A Contrast between European and English-Speaking Countries, Oxford: Oxford University Press

Piketty, Thomas (2005), "Top Income Shares in the Long Run: An Overview”, Journal of the European Economic Association 3(2-3), 1-11.

Piketty, Thomas and Emmanuel Saez (2007) "Income Inequality in the United States, 1913-1998", in Atkinson, Anthony B. and Thomas Piketty (eds.), Top Incomes over the Twentieth Century: A Contrast between European and EnglishSpeaking Countries, Oxford: Oxford University Press

Piketty, Thomas and Emmanuel Saez (2006) "The Evolution of Top Incomes: A Historical and International Perspective", American Economic Review, Papers and Proceedings 96(2), 200-205.

Rajan, Raghuram and Luigi Zingales (2003), "The Great Reversals: The Politics of Financial Development in the 20th Century", Journal of Financial Economics $69,5-50$.

Rodrik, Dani (1997), “Has Globalization Gone Too Far?”, Washington DC: Institute for International Economics.

Roine, Jesper and Daniel Waldenström (2009), “Top Incomes in Sweden over the twentieth century", in A.B. Atkinson and T. Piketty (eds.) (2009), Top Incomes: A Global Perspective. Volume II, Oxford: Oxford University Press.

Roodman, David (2007), "How to do xtabond2: An Introduction to 'Difference' and 'System' GMM in Stata”, Center for Global Development Working Paper 103.

Rosen, Sherwin (1981), "The Economics of Superstars", American Economic Review $71(5), 845-858$.

Rousseau, Peter and Richard Sylla (2003), "Financial Systems, Economic Growth, and Globalization". In Bordo, M., A. Taylor, and J. Williamson, eds., Globalization in Historical Perspective, Chicago: University of Chicago Press for the National Bureau of Economic Research.

Rydqvist, Kristian, Joshua Spizman and Ilya Strebulaev (2007), "The Evolution of Aggregate Stock Ownership: A Unified Explanation", mimeo, Binghampton University.

Scheve, Kenneth F. and Matthew J. Slaughter (2007), “A New Deal for Globalization", Foreign Affairs 84:4, 
Scheve, Kenneth F. and David Stasavage (2009), "Institutions, Partisanship, and Inequality in the Long Run, forthcoming in World Politics.

Steinmo, Sven (1993), Taxation and Democracy, New Haven and London: Yale University Press.

Winters, Allan, Niel McCulloch, and Andy McKay (2004), "Trade Liberalization and Poverty: The Evidence so Far," Journal of Economic Literature 62, 72-115.

Wooldridge, Jeffrey W. (2002) Econometric Analysis of Cross Section and Panel Data, Cambridge MA, MIT Press. 
Table 1: Variable definitions

\begin{tabular}{|c|c|c|}
\hline Variable & Variable definition & Source \\
\hline Top1 & $\begin{array}{l}\text { Share of total income earned by those with the } \\
1 \% \text { highest incomes (P99-100). }\end{array}$ & See Table A2. \\
\hline Top10-1 & $\begin{array}{l}\text { Income share of top } 10 \% \text { less share of top } 1 \% \\
\text { (P90-99). }\end{array}$ & See Table A2. \\
\hline Bot90 & $\begin{array}{l}\text { Income share of bottom nine deciles of the en- } \\
\text { tire income distribution }(\mathrm{P} 0-90) \text {. }\end{array}$ & See Table A2. \\
\hline Top $1 / 10$ & Top1/Top10-1 (P99-100/P90-99). & See Table A2. \\
\hline Top01/1 & $\begin{array}{l}\text { Income share of top } 0.1 \% \text { divided by income } \\
\text { share earned by the rest of top } 1 \% \text { (P99.9- } \\
100 / \text { P99-99.9). }\end{array}$ & See Table A2. \\
\hline Findev & $\begin{array}{l}\text { Financial development: Total capitalization as } \\
\text { the sum of Bankdeposits and Marketcap. }\end{array}$ & $\begin{array}{l}\text {-1950: Mitchell, RZ, Bordo; } \\
\text { 1950-: IFS, FSD, RZ. }\end{array}$ \\
\hline Bankdeposits & $\begin{array}{l}\text { Bank deposits: Share of commercial and savings } \\
\text { bank deposits in GDP. }\end{array}$ & $\begin{array}{l}\text {-1950: Mitchell, Bordo; } \\
\text { 1950-: IFS, FSD. }\end{array}$ \\
\hline Marketcap & $\begin{array}{l}\text { Stock market capitalization: Market value of } \\
\text { publicly listed stocks divided by GDP. }\end{array}$ & $\begin{array}{l}\text {-1975: RZ; } \\
\text { 1975-: IFS, FSD. }\end{array}$ \\
\hline Openness & $\begin{array}{l}\text { Trade openness: Imports plus exports divided by } \\
\text { GDP. }\end{array}$ & $\begin{array}{l}\text {-1950: Mitchell, LM, Bordo; } \\
\text { 1950-: IFS, FSD. }\end{array}$ \\
\hline Govspend & $\begin{array}{l}\text { Central government expenditure divided by } \\
\text { GDP. }\end{array}$ & $\begin{array}{l}\text {-1950: Mitchell, RS, Bordo; } \\
\text { 1950-: IFS, FSD. }\end{array}$ \\
\hline Margtax 1 & $\begin{array}{l}\text { Top marginal tax rate: Margtax } 2 \text { except for } \\
\text { Germany, Japan, Sweden, UK and US where it } \\
\text { is calculated for incomes } \approx 5 \times \text { GDPpc. }\end{array}$ & $\begin{array}{l}\text { Table A2, OECD, BCS, RW } \\
\text { and RSS. }\end{array}$ \\
\hline Margtax2 & Top marginal tax rate (statutory top rates) & Table A2, OECD \\
\hline Bank crisis & Share of bank crisis years in 5-year period & Bordo, LV \\
\hline Currency crisis & Share of currency crisis years in 5-year period & Bordo, LV \\
\hline Avetariff & Paid import taxes divded by imports & Clemens and Williamson (2004) \\
\hline Agrishare & Share of agricultiural production in GDP & Mitchell, WDI \\
\hline Patents & Stock of domestic patents & Madsen (2007) \\
\hline GDPpc & GDP per capita & Maddison (2006) \\
\hline Pop & Population & Maddison (2006) \\
\hline
\end{tabular}

Note: The exact set of sources for each country-period observation can be found in our web appendix at www.ifn.se/danielw.

Abbreviations: $\mathrm{BCS}=$ Bach, Corneo and Steiner (2005); Bordo = Bordo, Eichengreen, Klingebiel and Martinez-Peria (2001); CW = Clemens and Williamson (2007); FSD = Financial Structure Database; IFS = International Financial Statistics; LM = López-Córdoba and Meissner (2005); LV = Laeven and Valencia (2008); Mitchell = Mitchell (1995, 1998a, 1998b); OECD = OECDE world tax database; RS = Rousseau and Sylla (2003); RSS = Rydqvist, Spizman and Strebulaev (2007); RW = Roine and Waldenström (2006); RZ = Rajan and Zingales (2003); WDI = World Development Indicators (World Bank). 
Table 2: Income inequality data

\begin{tabular}{llccc}
\hline \multirow{2}{*}{ Country } & \multicolumn{1}{c}{ Source } & Full sample period & No. 5-year periods \\
\cline { 3 - 5 } & & & Top1 & Top10-1 \\
\hline Argentina & Alvaredo (2009) & $1932-1973^{\mathrm{a}}, 1997-2004$ & 9 & 0 \\
Australia & Atkinson and Leigh (2007) & $1921-2002$ & 17 & 13 \\
Canada & Saez and Veall (2007) & $1920-2001$ & 17 & 13 \\
Finland & Riiehlä et al. (2009) & $1966-1985^{\mathrm{a}}, 1990-2002$ & 8 & 8 \\
France & Piketty (2007) & $1915-1998$ & 18 & 18 \\
Germany & Dell (2009) & $1925-1938,1944-1998$ & 13 & 13 \\
India & Banerjee and Piketty (2009) & $1922-1999$ & 16 & 0 \\
Ireland & Nolan (2009) & $1938,1943,1965,1973-2000$ & 8 & 8 \\
Japan & Moriguchi and Saez (2007) & $1886-2002$ & 21 & $17^{\mathrm{b}}$ \\
Netherlands & Atkinson and Salverda (2007) & $1914-1999$ & 17 & 17 \\
New Zealand & Atkinson and Leigh (2007) & $1921-2002$ & 17 & 17 \\
Spain & Alvaredo and Saez (2009) & $1981-2002$ & 5 & 5 \\
Sweden & Roine and Waldenström (2009) & $1903-1935^{\mathrm{a}}, 1941-2004$ & 20 & 20 \\
Switzerland & Dell et al. (2007) & $1933-1996$ & 14 & 14 \\
United Kingdom & Atkinson and Salverda (2007) & $1908-1999$ & 14 & 14 \\
United States & Piketty and Saez (2007) & $1913-2002$ & 19 & 18 \\
\hline \hline
\end{tabular}

${ }^{\mathrm{a}}$ There are years with missing values in this subperiod

${ }^{b}$ The shares-within-shares data for Japan is based on the top five percent (P95-100).

Table 3: Summary statistcs for our main variables.

\begin{tabular}{lccccc}
\hline \hline Variable & Obs & Mean & Std. Dev. & Min & Max \\
\hline Top1 & 237 & 10.69 & 4.68 & 2.95 & 26.99 \\
Top10-1 & 182 & 23.36 & 2.89 & 16.00 & 30.68 \\
Bot90 & 182 & 66.76 & 5.99 & 49.86 & 81.05 \\
Top1/10 & 199 & 0.45 & 0.24 & 0.18 & 1.63 \\
Top01/1 & 236 & 0.46 & 0.17 & 0.17 & 0.93 \\
GDPpc & 508 & 7273 & 6070 & 513 & 28581 \\
Pop & 516 & 82073 & 181844 & 847 & 1287576 \\
Govspend & 475 & 0.14 & 0.06 & 0.01 & 0.49 \\
Findev & 280 & 0.94 & 0.54 & 0.06 & 3.61 \\
Openness & 446 & 0.40 & 0.36 & 0.02 & 3.66 \\
Margtax1 & 131 & 0.53 & 0.13 & 0.22 & 0.86 \\
Tariffs & 411 & 0.10 & 0.08 & 0.01 & 0.48 \\
Bankdeposits & 461 & 0.44 & 0.26 & 0.00 & 1.56 \\
Marketcap & 283 & 0.48 & 0.43 & 0.00 & 2.32 \\
Privatecredit & 264 & 0.60 & 0.39 & 0.04 & 1.95 \\
Bank crisis & 357 & 0.05 & 0.15 & 0.00 & 1.00 \\
Currency crisis & 357 & 0.06 & 0.12 & 0.00 & 0.60 \\
Agrishare & 296 & 16.34 & 14.50 & 1.00 & 61.00 \\
Patents & 399 & 14122 & 40091 & 3 & 370677 \\
\hline \hline
\end{tabular}


Table 4: Correlation matrix for our main variables.

\begin{tabular}{lcccccccc}
\hline \hline & Top1 & Top10-1 & Bot90 & GDPpc & Pop & Govspend & Findev & Openness Margtax1 \\
\hline Top1 & 1.00 & & & & & & & \\
Top10-1 & $0.41^{*}$ & 1.00 & & & & & & \\
Bot90 & $-0.90^{*}$ & $-0.77^{*}$ & 1.00 & & & & & \\
GDPpc & $-0.45^{*}$ & -0.01 & $0.29^{*}$ & 1.00 & & & & \\
Pop & -0.14 & -0.19 & 0.19 & $-0.20^{*}$ & 1.00 & & & \\
Govspend & $-0.40^{*}$ & -0.11 & $0.33^{*}$ & $0.52^{*}$ & -0.07 & 1.00 & & \\
Findev & 0.03 & 0.15 & -0.17 & $0.42^{*}$ & $-0.21^{*}$ & 0.09 & 1.00 & \\
Openness & $-0.27^{*}$ & -0.03 & 0.17 & $0.29^{*}$ & $-0.18^{*}$ & 0.10 & $0.27^{*}$ & 1.00 \\
Margtax1 & $-0.49^{*}$ & -0.20 & $0.34^{*}$ & -0.16 & -0.18 & 0.05 & $-0.37^{*}$ & -0.02 \\
\hline \hline
\end{tabular}


Table 5. The determinants of top income shares

\begin{tabular}{|c|c|c|c|c|c|c|c|c|c|c|}
\hline & $\begin{array}{c}(1) \\
\Delta \text { top1 }\end{array}$ & $\begin{array}{c}(2) \\
\Delta \text { top1 } \\
\end{array}$ & $\begin{array}{c}(3) \\
\Delta \text { top10-1 }\end{array}$ & $\begin{array}{c}(4) \\
\Delta \text { top10-1 }\end{array}$ & $\begin{array}{c}(5) \\
\Delta \text { bot90 }\end{array}$ & $\begin{array}{c}(6) \\
\Delta \text { bot90 }\end{array}$ & $\begin{array}{c}(7) \\
\Delta \text { top1/10 }\end{array}$ & $\begin{array}{c}(8) \\
\Delta \text { top1/10 }\end{array}$ & $\begin{array}{c}(9) \\
\Delta \text { top01/1 }\end{array}$ & $\begin{array}{c}(10) \\
\Delta \text { top01/1 }\end{array}$ \\
\hline$\Delta \mathrm{GDPpc}$ & $\begin{array}{c}5.77 * * * \\
(1.03)\end{array}$ & $\begin{array}{c}6.42 * * * \\
(1.34)\end{array}$ & $\begin{array}{c}-8.78 * * * \\
(1.73)\end{array}$ & $\begin{array}{c}-6.90 * * * \\
(2.61)\end{array}$ & $\begin{array}{c}5.56 * * \\
(2.73)\end{array}$ & $\begin{array}{l}-1.30 \\
(3.53)\end{array}$ & $\begin{array}{c}0.28 * * * \\
(0.05)\end{array}$ & $\begin{array}{c}0.36 * * * \\
(0.06)\end{array}$ & $\begin{array}{c}0.23 * * * \\
(0.05)\end{array}$ & $\begin{array}{c}0.26 * * * \\
(0.06)\end{array}$ \\
\hline$\Delta$ Pop & $\begin{array}{l}-4.62 \\
(5.03)\end{array}$ & $\begin{array}{c}-12.98 * * \\
(5.62)\end{array}$ & $\begin{array}{l}-0.57 \\
(6.31)\end{array}$ & $\begin{array}{c}-12.20 \\
(8.04)\end{array}$ & $\begin{array}{c}9.83 \\
(11.54)\end{array}$ & $\begin{array}{c}24.09 * * \\
(12.02)\end{array}$ & $\begin{array}{l}-0.23 \\
(0.22)\end{array}$ & $\begin{array}{c}-0.66^{* * *} \\
(0.22)\end{array}$ & $\begin{array}{c}0.02 \\
(0.21)\end{array}$ & $\begin{array}{c}-0.37^{*} \\
(0.22)\end{array}$ \\
\hline$\Delta$ Govspend & $\begin{array}{c}5.77 \\
(4.62)\end{array}$ & $\begin{array}{c}3.35 \\
(4.66)\end{array}$ & $\begin{array}{c}-16.28 * * * \\
(4.99)\end{array}$ & $\begin{array}{c}-23.40 * * * \\
(7.11)\end{array}$ & $\begin{array}{c}22.39 * * * \\
(8.53)\end{array}$ & $\begin{array}{c}23.96 * * * \\
(8.89)\end{array}$ & $\begin{array}{l}-0.10 \\
(0.18)\end{array}$ & $\begin{array}{c}0.12 \\
(0.19)\end{array}$ & $\begin{array}{l}-0.20 \\
(0.20)\end{array}$ & $\begin{array}{l}-0.25 \\
(0.21)\end{array}$ \\
\hline$\Delta$ Findev & $\begin{array}{c}0.99 * * * \\
(0.32)\end{array}$ & $\begin{array}{c}1.27 * * * \\
(0.30)\end{array}$ & $\begin{array}{c}0.16 \\
(0.33)\end{array}$ & $\begin{array}{c}0.19 \\
(0.44)\end{array}$ & $\begin{array}{l}-0.53 \\
(0.62)\end{array}$ & $\begin{array}{c}-1.89 * * * \\
(0.66)\end{array}$ & $\begin{array}{c}0.03 * * * \\
(0.01)\end{array}$ & $\begin{array}{c}0.06 * * * \\
(0.01)\end{array}$ & $\begin{array}{c}0.02 \\
(0.01)\end{array}$ & $\begin{array}{c}0.03 * * * \\
(0.01)\end{array}$ \\
\hline$\Delta$ Openness & $\begin{array}{c}-8.83^{* * *} \\
(2.26)\end{array}$ & $\begin{array}{l}-2.46 \\
(2.55)\end{array}$ & $\begin{array}{l}-0.24 \\
(2.42)\end{array}$ & $\begin{array}{c}0.41 \\
(3.75)\end{array}$ & $\begin{array}{c}3.29 \\
(4.40)\end{array}$ & $\begin{array}{c}0.14 \\
(5.05)\end{array}$ & $\begin{array}{l}-0.01 \\
(0.08)\end{array}$ & $\begin{array}{l}-0.06 \\
(0.09)\end{array}$ & $\begin{array}{l}-0.07 \\
(0.09)\end{array}$ & $\begin{array}{c}0.14 \\
(0.11)\end{array}$ \\
\hline$\Delta$ Margtax 1 & & $\begin{array}{c}-4.34 * * * \\
(1.21)\end{array}$ & & $\begin{array}{c}-3.22 * * \\
(1.56)\end{array}$ & & $\begin{array}{c}10.22 * * * \\
(2.21)\end{array}$ & & $\begin{array}{c}-0.15^{* * *} \\
(0.04)\end{array}$ & & $\begin{array}{c}-0.30 * * * \\
(0.05)\end{array}$ \\
\hline Obs & 126 & 92 & 99 & 77 & 99 & 77 & 109 & 87 & 126 & 92 \\
\hline $\mathrm{N}$ countries & 14 & 12 & 12 & 10 & 12 & 10 & 13 & 11 & 14 & 12 \\
\hline
\end{tabular}


Table 6. The effects at different levels of economic development

\begin{tabular}{|c|c|c|c|c|}
\hline & $\begin{array}{c}(1) \\
\Delta \text { top1 }\end{array}$ & $\begin{array}{c}(2) \\
\Delta \text { top1 }\end{array}$ & $\begin{array}{c}(3) \\
\Delta \text { top10-1 }\end{array}$ & $\begin{array}{c}(4) \\
\Delta \text { top10-1 }\end{array}$ \\
\hline$\Delta \mathrm{GDPpc}$ & & $\begin{array}{c}5.39 * * * \\
(1.06)\end{array}$ & & $\begin{array}{c}-8.52 * * * \\
(1.71)\end{array}$ \\
\hline$\Delta$ Pop & $\begin{array}{l}-4.90 \\
(5.03)\end{array}$ & $\begin{array}{l}-5.86 \\
(5.18)\end{array}$ & $\begin{array}{l}-2.78 \\
(6.64)\end{array}$ & $\begin{array}{c}4.16 \\
(6.44)\end{array}$ \\
\hline$\Delta$ Govspend & $\begin{array}{c}3.38 \\
(4.72)\end{array}$ & $\begin{array}{c}5.75 \\
(4.65)\end{array}$ & $\begin{array}{c}-17.79 * * * \\
(5.39)\end{array}$ & $\begin{array}{c}-18.87 * * * \\
(4.83)\end{array}$ \\
\hline$\Delta$ Findev & $\begin{array}{c}1.05 * * * \\
(0.33)\end{array}$ & & $\begin{array}{c}0.20 \\
(0.33)\end{array}$ & \\
\hline$\Delta$ Openness & $\begin{array}{c}-9.15 * * * \\
(2.26)\end{array}$ & $\begin{array}{c}-8.49 * * * \\
(2.26)\end{array}$ & $\begin{array}{l}-0.34 \\
(2.45)\end{array}$ & $\begin{array}{l}-0.78 \\
(2.31)\end{array}$ \\
\hline$\Delta \mathrm{GDPpc} \times$ Lowdev & $\begin{array}{c}5.04 * * * \\
(1.13)\end{array}$ & & $\begin{array}{c}-9.02 * * * \\
(2.08)\end{array}$ & \\
\hline$\Delta \mathrm{GDPpc} \times$ Meddev & $\begin{array}{c}6.37 * * * \\
(1.50)\end{array}$ & & $\begin{array}{c}-7.32 * * * \\
(2.40)\end{array}$ & \\
\hline$\Delta$ GDPpc $\times$ Highdev & $\begin{array}{c}2.45 \\
(2.26)\end{array}$ & & $\begin{array}{c}-9.77 * * * \\
(2.69)\end{array}$ & \\
\hline$\Delta$ Findev $\times$ Lowdev & & $\begin{array}{l}1.67 * \\
(0.94)\end{array}$ & & $\begin{array}{c}-3.27 * * \\
(1.37)\end{array}$ \\
\hline$\Delta$ Findev $\times$ Meddev & & $\begin{array}{l}0.88 * \\
(0.52)\end{array}$ & & $\begin{array}{c}0.33 \\
(0.63)\end{array}$ \\
\hline$\Delta$ Findev $\times$ Highdev & & $\begin{array}{l}0.86^{*} \\
(0.44)\end{array}$ & & $\begin{array}{c}0.38 \\
(0.37) \\
\end{array}$ \\
\hline F-test: Low $=$ Med $^{\mathrm{a}}$ & 0.31 & 0.45 & 0.52 & 0.02 \\
\hline F-test: Low $=$ High $^{\mathrm{a}}$ & 0.25 & 0.42 & 0.80 & 0.01 \\
\hline F-test: $\mathrm{Med}=\mathrm{High}^{\mathrm{a}}$ & 0.07 & 0.98 & 0.34 & 0.94 \\
\hline Obs & 126 & 126 & 99 & 99 \\
\hline $\mathrm{N}$ countries & 14 & 14 & 12 & 12 \\
\hline
\end{tabular}

Notes: Interactions between low, medium and high GDP per capita and $\Delta$ GDPpc and $\Delta$ Findev. See also the notes of Table 5. ${ }^{\text {a }} \mathrm{P}$-value of an $\mathrm{F}$-test of equality of coefficients. 
Table 7. The impact of banking and currency crises

\begin{tabular}{lcccc}
\hline \hline & $(1)$ & $(2)$ & $(3)$ & $(4)$ \\
& $\Delta$ top 1 & $\Delta$ top1 & $\Delta$ top10-1 & $\Delta$ top10-1 \\
\hline Bank crisis & $-1.07^{* * *}$ & $-1.08^{* * *}$ & 0.33 & 0.35 \\
& $(0.39)$ & $(0.39)$ & $(0.38)$ & $(0.37)$ \\
Currency crisis & & -0.06 & & -0.31 \\
& & $(0.45)$ & & $(0.55)$ \\
\hline Control variables incl. & Yes & Yes & Yes & Yes \\
Obs & 171 & 171 & 132 & 132 \\
N countries & 17 & 17 & 14 & 14
\end{tabular}

Note: FDGLS regressions with constant and fixed effects for period and country trends suppressed. Bank crises and currency crises is the share of years in each 5-year period being classified as "crises years" by Bordo et al (2001) and Laeven and Valencia (2008). The regressions include $\Delta$ GDPpc, $\Delta$ Openness, $\Delta$ Pop and $\Delta$ Govspend. See also the notes of Table 5. 
Table 8. Bank- and market based financial systems

\begin{tabular}{lcccccc}
\hline \hline & $(1)$ & $(2)$ & $(3)$ & $(4)$ & $(5)$ & $(6)$ \\
& $\Delta$ top1 & $\Delta$ top1 & $\Delta$ top1 & $\Delta$ top10-1 & $\Delta$ top10-1 & $\Delta$ top10-1 \\
\hline$\Delta$ Bankdeposits & $3.01^{* * *}$ & & & 0.30 & & \\
& $(0.80)$ & & & $(0.89)$ & & \\
$\Delta$ Marketcap & & $0.88^{* *}$ & & & $(0.39)$ & -0.77 \\
& & $(0.38)$ & & & & $(0.61)$ \\
$\Delta$ Private credit & & & $0.87^{* *}$ & & Yes & Yes \\
& & & $(0.44)$ & & 101 & 112 \\
Control variables inc. & Yes & Yes & Yes & Yes & 13 & 13 \\
Obs & 168 & 128 & 130 & 129 & 13 & 13 \\
N countries & 16 & 15 & 15 & & & \\
\hline \hline
\end{tabular}

Note: Financial development is split into Bank deposits and Market capitalization. The regressions include $\Delta$ GDPpc, $\Delta$ Openness, $\Delta$ Pop and $\Delta$ Govspend. See also the notes of Table 5. 
Table 9: Are Anglo-Saxon countries different?

\begin{tabular}{|c|c|c|c|c|}
\hline & $\begin{array}{c}(1) \\
\Delta \text { top1 }\end{array}$ & $\begin{array}{c}(2) \\
\Delta \text { top1 }\end{array}$ & $\begin{array}{c}(3) \\
\Delta \text { top10-1 }\end{array}$ & $\begin{array}{c}(4) \\
\Delta \text { top10-1 }\end{array}$ \\
\hline$\Delta \mathrm{GDPpc}$ & $\begin{array}{c}5.62 * * * \\
(1.13)\end{array}$ & $\begin{array}{c}5.50 * * * \\
(1.04)\end{array}$ & $\begin{array}{c}-9.44 * * * \\
(1.98)\end{array}$ & $\begin{array}{c}-9.21 * * * \\
(1.73)\end{array}$ \\
\hline$\Delta$ Pop & $\begin{array}{l}-4.79 \\
(5.06)\end{array}$ & $\begin{array}{l}-4.42 \\
(4.94)\end{array}$ & $\begin{array}{l}-0.29 \\
(6.29)\end{array}$ & $\begin{array}{c}1.79 \\
(6.42)\end{array}$ \\
\hline$\Delta$ Govspend & $\begin{array}{c}5.87 \\
(4.63)\end{array}$ & $\begin{array}{c}5.64 \\
(4.61)\end{array}$ & $\begin{array}{c}-15.61 * * * \\
(4.91)\end{array}$ & $\begin{array}{c}-16.78^{* * * *} \\
(5.00)\end{array}$ \\
\hline$\Delta$ Findev & $\begin{array}{c}1.00 * * * \\
(0.32)\end{array}$ & $\begin{array}{c}0.98 * * * \\
(0.31)\end{array}$ & $\begin{array}{c}0.18 \\
(0.33)\end{array}$ & $\begin{array}{c}0.18 \\
(0.33)\end{array}$ \\
\hline$\Delta$ Openness & $\begin{array}{c}-8.84 * * * \\
(2.26)\end{array}$ & $\begin{array}{c}-9.91 * * * \\
(2.42)\end{array}$ & $\begin{array}{c}0.41 \\
(2.69)\end{array}$ & $\begin{array}{l}-1.51 \\
(2.50)\end{array}$ \\
\hline$\Delta$ GDPpc $\times$ Anglo-Saxon & $\begin{array}{c}0.42 \\
(1.59)\end{array}$ & & $\begin{array}{c}1.95 \\
(2.27)\end{array}$ & \\
\hline$\Delta$ Openness $\times$ Anglo-Saxon & & $\begin{array}{c}3.08 \\
(2.56)\end{array}$ & & $\begin{array}{c}5.96 \\
(3.98)\end{array}$ \\
\hline Obs & 126 & 126 & 99 & 99 \\
\hline $\mathrm{N}$ countries & 14 & 14 & 12 & 12 \\
\hline
\end{tabular}

Notes: Interacting a dummy for Anglo-Saxon countries (Australia, Canada, New Zealand, U.K. and U.S.) and $\Delta$ GDPpc and $\Delta$ Openness. See also the notes of Table 1. 
Table 10. Sample restrictions and alternative measures

\begin{tabular}{|c|c|c|c|c|c|c|c|c|c|c|}
\hline & $\begin{array}{c}(1) \\
\Delta \text { top1 }\end{array}$ & $\begin{array}{c}(2) \\
\Delta \text { top1 }\end{array}$ & $\begin{array}{c}(3) \\
\Delta \text { top1 }\end{array}$ & $\begin{array}{c}(4) \\
\Delta \text { top1 }\end{array}$ & $\begin{array}{c}(5) \\
\Delta \text { top1 }\end{array}$ & $\begin{array}{c}(6) \\
\Delta \text { top10-1 }\end{array}$ & $\begin{array}{c}(7) \\
\Delta \text { top10-1 }\end{array}$ & $\begin{array}{c}(8) \\
\Delta \text { top10-1 }\end{array}$ & $\begin{array}{c}(9) \\
\Delta \text { top10-1 }\end{array}$ & $\begin{array}{c}(10) \\
\Delta \text { top10-1 }\end{array}$ \\
\hline$\Delta \mathrm{GDPpc}$ & $\begin{array}{c}5.16 * * * \\
(1.02)\end{array}$ & $\begin{array}{c}5.81 * * * \\
(1.30)\end{array}$ & $\begin{array}{c}6.27 * * * \\
(1.31)\end{array}$ & $\begin{array}{c}5.39 * * * \\
(1.19)\end{array}$ & $\begin{array}{c}-7.49 * * * \\
(2.22)\end{array}$ & $\begin{array}{c}-7.03 * * * \\
(1.84)\end{array}$ & $\begin{array}{c}-8.48 * * * \\
(1.47)\end{array}$ & $\begin{array}{c}-10.00 * * * \\
(1.97)\end{array}$ & $\begin{array}{c}-6.33 * * * \\
(2.06)\end{array}$ & $\begin{array}{c}-8.71 * * * \\
(1.74)\end{array}$ \\
\hline$\Delta \mathrm{Pop}$ & $\begin{array}{l}-7.64 \\
(5.09)\end{array}$ & $\begin{array}{c}4.12 \\
(5.59)\end{array}$ & $\begin{array}{l}-4.36 \\
(5.25)\end{array}$ & $\begin{array}{l}-2.18 \\
(4.66)\end{array}$ & $\begin{array}{c}4.62 * * * \\
(1.13)\end{array}$ & $\begin{array}{l}-5.37 \\
(6.52)\end{array}$ & $\begin{array}{c}10.68 * * \\
(5.31)\end{array}$ & $\begin{array}{c}-12.35 * \\
(7.16)\end{array}$ & $\begin{array}{c}8.10 \\
(9.31)\end{array}$ & $\begin{array}{l}-1.72 \\
(6.31)\end{array}$ \\
\hline$\Delta$ Govspend & $\begin{array}{l}-1.49 \\
(4.23)\end{array}$ & $\begin{array}{c}4.44 \\
(5.06)\end{array}$ & $\begin{array}{c}13.01 * * * \\
(4.97)\end{array}$ & $\begin{array}{c}3.85 \\
(5.57)\end{array}$ & $\begin{array}{c}2.68 \\
(4.92)\end{array}$ & $\begin{array}{c}-17.04 * * * \\
(4.98)\end{array}$ & $\begin{array}{c}-11.25^{* *} \\
(5.60)\end{array}$ & $\begin{array}{c}-17.88^{* * *} \\
(6.52)\end{array}$ & $\begin{array}{c}-24.21 * * * \\
(6.12)\end{array}$ & $\begin{array}{c}-16.31 * * * \\
(4.97)\end{array}$ \\
\hline$\Delta$ Findev & $\begin{array}{c}0.63 * * \\
(0.28)\end{array}$ & $\begin{array}{l}0.61 * \\
(0.35)\end{array}$ & $\begin{array}{c}1.28 * * * \\
(0.32)\end{array}$ & $\begin{array}{l}1.90 * * \\
(0.91)\end{array}$ & $\begin{array}{c}4.86 \\
(4.48)\end{array}$ & $\begin{array}{c}0.36 \\
(0.31)\end{array}$ & $\begin{array}{l}1.35^{\mathrm{a}} \\
(0.94)\end{array}$ & $\begin{array}{c}0.08 \\
(0.42)\end{array}$ & $\begin{array}{l}-0.32 \\
(0.50)\end{array}$ & $\begin{array}{c}0.24 \\
(0.32)\end{array}$ \\
\hline$\Delta$ Openness & $\begin{array}{l}-0.78 \\
(2.34)\end{array}$ & & $\begin{array}{c}-8.40 * * * \\
(2.52)\end{array}$ & $\begin{array}{c}-3.35 * * \\
(1.67)\end{array}$ & $\begin{array}{c}1.10 * * * \\
(0.31)\end{array}$ & $\begin{array}{l}-0.01 \\
(2.57)\end{array}$ & & $\begin{array}{c}0.52 \\
(3.31)\end{array}$ & $\begin{array}{l}-2.95 \\
(3.10)\end{array}$ & $\begin{array}{l}-0.32 \\
(2.45)\end{array}$ \\
\hline$\Delta$ Tariffs & & $\begin{array}{c}2.40 \\
(2.60)\end{array}$ & & & & & $\begin{array}{c}3.96 \\
(4.30)\end{array}$ & & & \\
\hline$\Delta$ Margtax 2 & & & $\begin{array}{c}-2.10 * * \\
(0.93)\end{array}$ & & & & & $\begin{array}{c}-2.89 * * * \\
(1.08)\end{array}$ & & \\
\hline$\Delta$ Agrishare & & & & $\begin{array}{l}-0.04 \\
(0.04)\end{array}$ & & & & & $\begin{array}{l}-0.03 \\
(0.09)\end{array}$ & \\
\hline$\Delta$ Patents & & & & & $\begin{array}{l}-0.00 \\
(0.00) \\
\end{array}$ & & & & & $\begin{array}{c}0.00 \\
(0.00) \\
\end{array}$ \\
\hline Restriction & Postwar & Tariffs & Margtax2 & Agrishare & Patents & Postwar & Tariffs & Margtax2 & Agrishare & Patents \\
\hline Obs & 112 & 110 & 103 & 142 & 115 & 93 & 114 & 82 & 91 & 99 \\
\hline $\mathrm{N}$ countries & 14 & 14 & 12 & 15 & 13 & 12 & 13 & 10 & 11 & 12 \\
\hline
\end{tabular}

Note: Postwar = sample is 1945 onwards, Tariffs = we switch openness measure to the de jure measure Tariffs, Margtax2 = Margtax2 replaces Margtax1, Agrishare = technological development as GDP-share of agriculture and Patents $=$ technological development as patents. See also the notes of Table $1 .{ }^{\text {a }}$ denotes that $\Delta$ Bankdeposits was used instead of $\Delta$ Findev because otherwise we had too few degrees of freedom when also using the Tariff variable. 
Figure 1: Top income percentile share for 16 countries over the twentieth century.

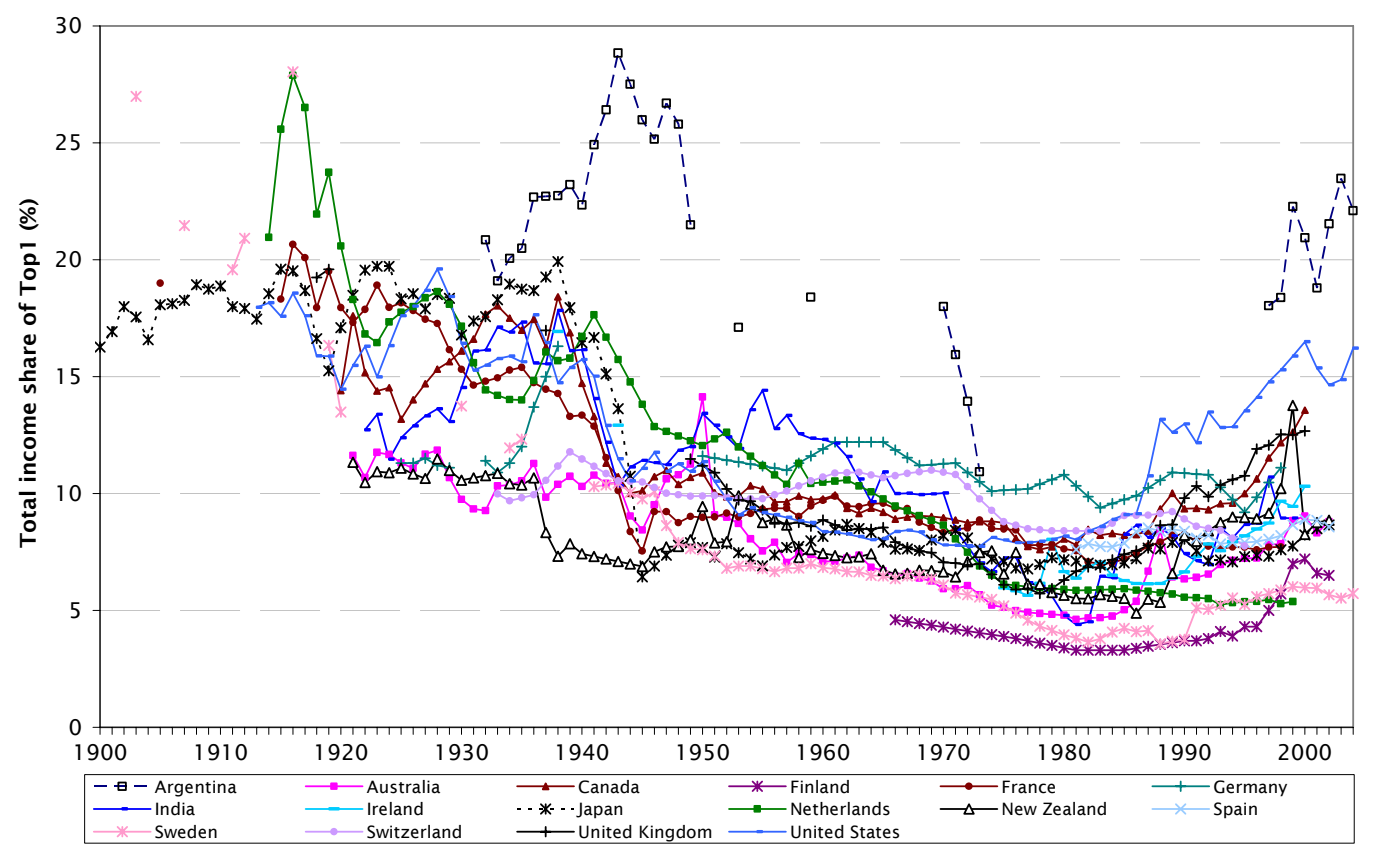

Source: See Table A2. 
Figure 2: Variables included in the regression analysis, all countries, 1900-2000.

a) Total capitalization

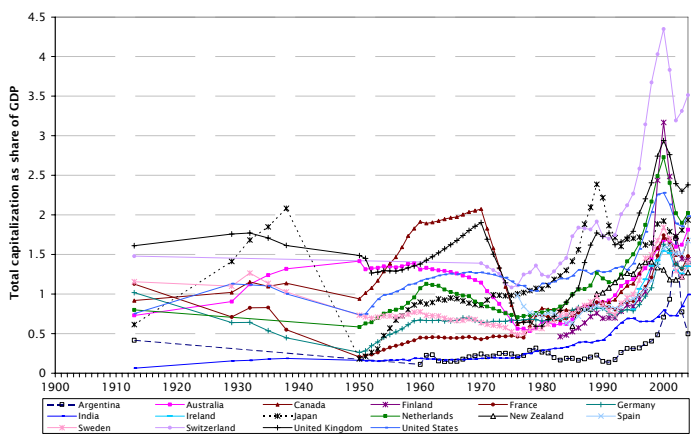

c) Stock market capitalization

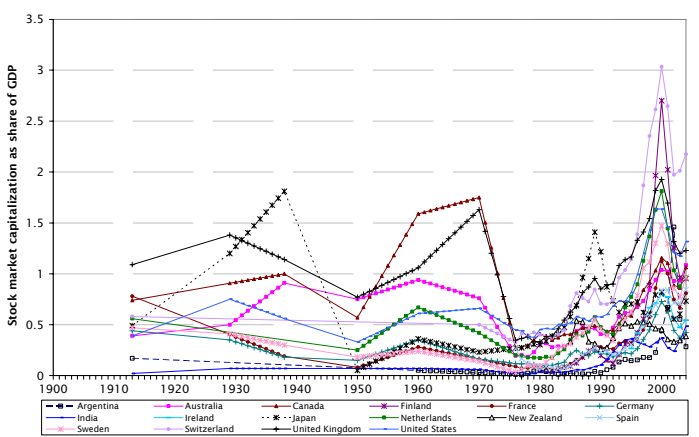

e) GDP per capita

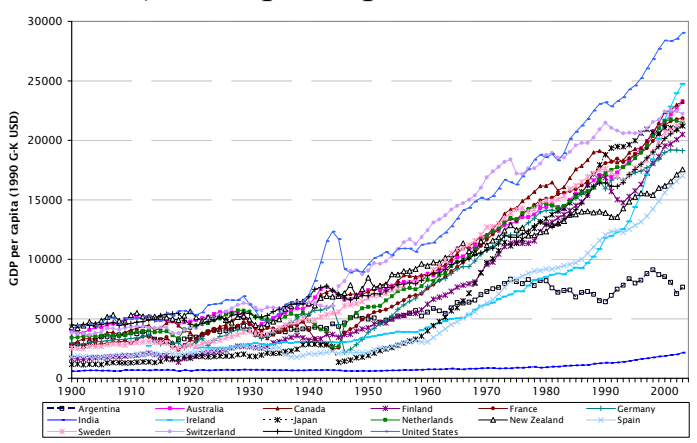

g) Top marginal tax rate 1

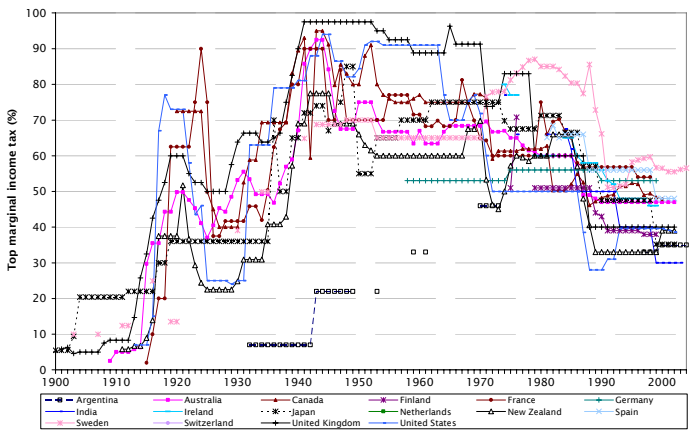

b) Bank deposits

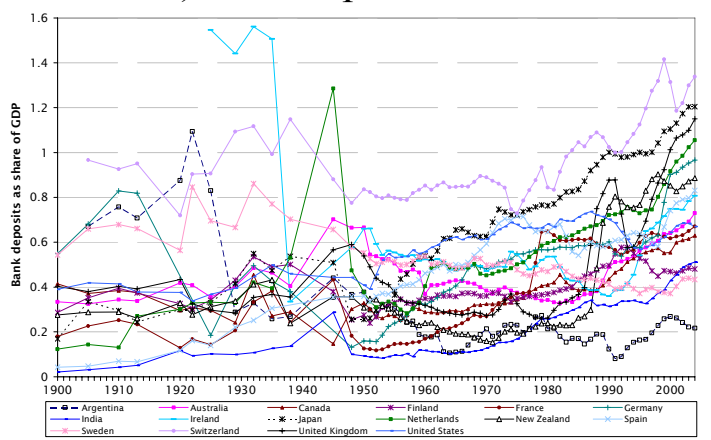

d) Trade openness

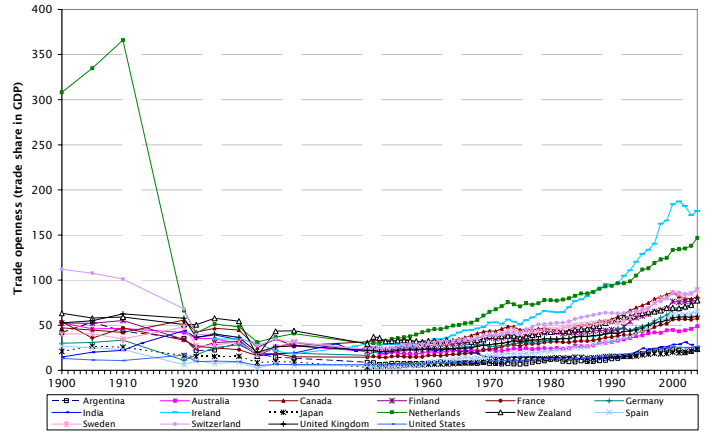

f) Government spending

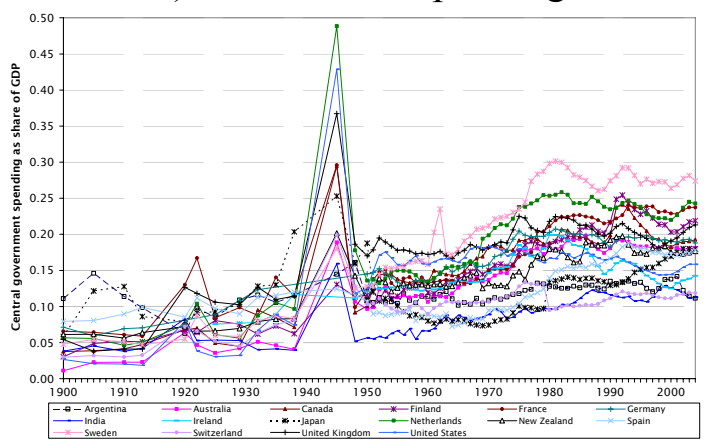

h) Top marginal tax rate 2

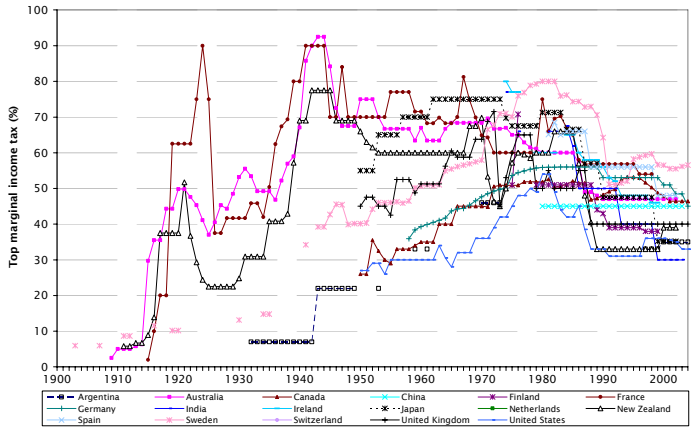


Figure 3. Anglo-Saxon deviations from common time trend

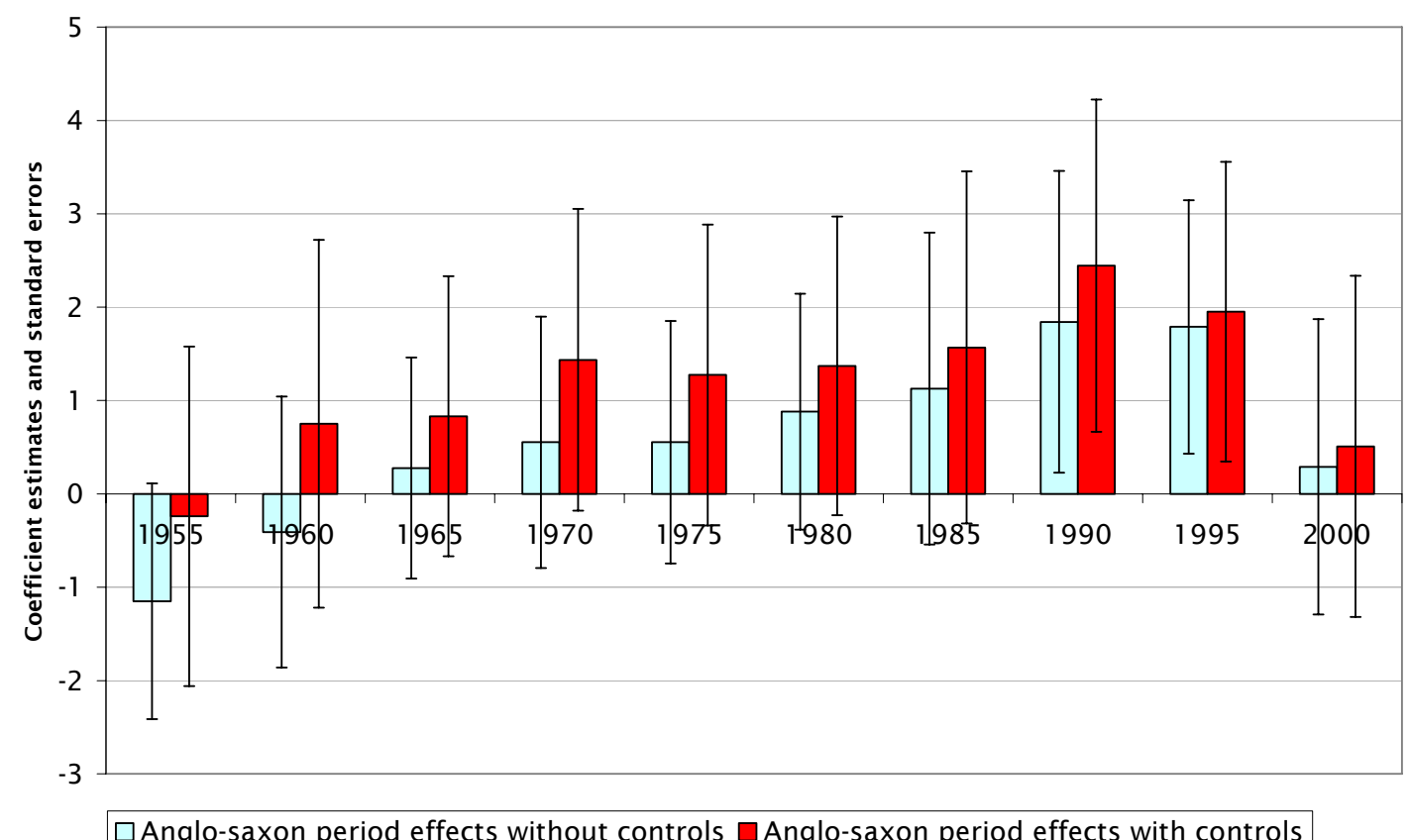

Note: The graph displays the interaction terms between time fixed effects and an Anglo-Saxon dummy, with and without our base set of control variables. 95 percent confidence intervals indicated. 


\section{Appendix A: Simulations of dynamic effects of taxation and shocks to capital}

The tables below show the cumulative effects on top incomes from increases in taxation and shocks to the capital stock under very stylized assumptions. ${ }^{53}$ In all cases we assume that there are two groups of income earners; a top group that derives half their income from capital (the rate of return is assumed to be 5 percent) and the other half from wages, while the rest only have a wage income. Initially the income share of the top group is 15 percent of all income and their consumption is such that their capital stock remains unchanged. These assumptions are of course not calibrated to fit a particular economy but they are at the same time approximate representations of the relationship between the top percentile and the rest of the population, both in terms of the importance of capital (with a broad interpretation) and the income share around World War II.

Gross wage income is assumed to be unchanged when taxes change implying that the (gross) income remains the same over time forcing wage earners to alter consumption as taxes increases (alternatively one could think of this as a case where their effective consumption can be maintained through taxes being redistributed back to them). The rich group, however, can consume part of their capital stock so as to maintain their consumption level. This, of course, erodes their capital stock, giving rise to a decreasing capital income share, and also a decreasing top income share.

Table A1 shows the effects of a tax increase from 0.3 to 0.6 in period 0 (columns 1-3), the effects of a shock to the capital stock causing 30 percent of it to disappear in period 0 (columns 4-6) and finally the combined effect of these changes given that the rich group does not alter consumption. With respect to the effects of taxation it illustrates that a one time change can have a small effect in the short run but through its cumulative effect can be important over time. Looking first at the effect from a tax increase, the instantaneous decrease in the the top income share is only 0.2 percentage points. However, after five years the effect has grown to 0.8 percentage points, and after 25 periods the effect is over 6 percentage points. The effect of a 30 percent loss

\footnotetext{
${ }^{53}$ The assumptions we make are very similar to those in a similar exercise in Piketty (2001b).
} 
of capital is approximately of the same order of magnitude (given these assumptions) and combined the effect is substantial already after a decade.

Table A1. Cumulative effect of one time changes affecting the capital stock and capital income

\begin{tabular}{c|ccc|ccc|ccc}
\hline \hline & \multicolumn{2}{|c|}{$\begin{array}{c}\text { Tax increase only (no change } \\
\text { in capital stock) }\end{array}$} & \multicolumn{2}{c|}{$\begin{array}{c}\text { Shock to the capital stock only } \\
\text { (no tax increase) }\end{array}$} & \multicolumn{2}{c}{$\begin{array}{c}\text { Combined tax increase and } \\
\text { shock to the capital stock }\end{array}$} \\
\hline \multirow{2}{*}{ Period } & $\begin{array}{c}(1) \\
\text { Remaining } \\
\text { capital } \\
\text { stock }\end{array}$ & $\begin{array}{c}\text { Capital } \\
\text { income } \\
\text { share }\end{array}$ & $\begin{array}{c}\text { Top in- } \\
\text { come } \\
\text { share }\end{array}$ & $\begin{array}{c}\text { Remaining } \\
\text { capital } \\
\text { stock }\end{array}$ & $\begin{array}{c}\text { Capital } \\
\text { income } \\
\text { share }\end{array}$ & $\begin{array}{c}\text { Top in- } \\
\text { come } \\
\text { share }\end{array}$ & $\begin{array}{c}\text { Remaining } \\
\text { capital } \\
\text { stock }\end{array}$ & $\begin{array}{c}\text { Capital } \\
\text { income } \\
\text { share }\end{array}$ & $\begin{array}{c}\text { Top in- } \\
\text { come } \\
\text { share }\end{array}$ \\
\hline 0 & $100.0 \%$ & $50.0 \%$ & $15.00 \%$ & $100.0 \%$ & $50.0 \%$ & $15.00 \%$ & $100.0 \%$ & $50.0 \%$ & $15.00 \%$ \\
\hline 5 & $87.6 \%$ & $46.7 \%$ & $14.20 \%$ & $65.6 \%$ & $39.6 \%$ & $12.75 \%$ & $55.2 \%$ & $36.9 \%$ & $12.27 \%$ \\
10 & $70.7 \%$ & $41.4 \%$ & $13.09 \%$ & $59.1 \%$ & $37.2 \%$ & $12.31 \%$ & $34.9 \%$ & $29.9 \%$ & $11.18 \%$ \\
15 & $52.1 \%$ & $34.2 \%$ & $11.83 \%$ & $51.4 \%$ & $34.0 \%$ & $11.79 \%$ & 0 & 0 & $8.11 \%$ \\
20 & $31.5 \%$ & $23.9 \%$ & $10.40 \%$ & $42.3 \%$ & $29.7 \%$ & $11.16 \%$ & 0 & 0 & $8.11 \%$ \\
25 & $8.7 \%$ & $8.0 \%$ & $8.75 \%$ & $31.5 \%$ & $24.0 \%$ & $10.40 \%$ & 0 & 0 & $8.11 \%$ \\
\hline \hline
\end{tabular}

Note: In period 0 there is a one time change which has cummulative effects. Columns (1)-(3) show the effects of a tax increase from 30 to 60 percent, columns (4)-(6) the effects of a shock to the capital stock such that it decreases to 70 percent of it's initial value, and columns (7)-(9) show the effects of these two changes in combination. All calculations are made based on the assumption that consumption is not adjusted (see Table 2 for the effect of adjusting this).

Table A2 shows the results of the same exercise but changing the increases in taxation up and down and also changing the size of the capital shock, as well as when changing consumption. The results are intuitively clear: higher tax increases cause the capital to shrink faster as does larger shocks to capital under the assumption that consumption is to remain unchanged and decreasing consumption can lead to a recovery of the capital stock. Again what is important to note is the potential cumulative effect of taxation when interpreting our coefficients which are the estimated instantaneous effects. Even if these are relatively small the dynamic effect can be important over time. 
Table A2. Cumulative effects of different changes to taxes and the capital stock, as well as with consumption adjustment

\begin{tabular}{|c|c|c|c|c|c|c|c|c|c|}
\hline \multirow[b]{3}{*}{ Year } & \multicolumn{3}{|c|}{ Tax increase } & \multicolumn{3}{|c|}{ Shock to the capital stock } & \multicolumn{3}{|c|}{$\begin{array}{l}\text { Combined tax increase and } \\
\text { shock to the capital stock }\end{array}$} \\
\hline & $(1)$ & $(2)$ & (3) & (4) & $(5)$ & (6) & $(7)$ & $(8)$ & (9) \\
\hline & $\begin{array}{l}\text { Remaining } \\
\text { capital } \\
\text { stock }\end{array}$ & $\begin{array}{l}\text { Capital } \\
\text { income } \\
\text { share }\end{array}$ & $\begin{array}{l}\text { Top in- } \\
\text { come } \\
\text { share }\end{array}$ & $\begin{array}{l}\text { Remaining } \\
\text { capital } \\
\text { stock }\end{array}$ & $\begin{array}{l}\text { Capital } \\
\text { income } \\
\text { share }\end{array}$ & $\begin{array}{l}\text { Top in- } \\
\text { come } \\
\text { share }\end{array}$ & $\begin{array}{l}\text { Remaining } \\
\text { capital } \\
\text { stock }\end{array}$ & $\begin{array}{l}\text { Capital } \\
\text { income } \\
\text { share }\end{array}$ & $\begin{array}{l}\text { Top in- } \\
\text { come } \\
\text { share }\end{array}$ \\
\hline \multirow[t]{2}{*}{0} & $100.0 \%$ & $50.0 \%$ & $15.00 \%$ & $100.0 \%$ & $50.0 \%$ & $15.00 \%$ & $100.0 \%$ & $50.0 \%$ & $15.00 \%$ \\
\hline & \multicolumn{3}{|c|}{ Tax increase from 0.3 to 0.4} & \multicolumn{3}{|c|}{ Capital shock, $90 \%$ remaining } & \multicolumn{3}{|c|}{ Combined effect } \\
\hline 5 & $95.8 \%$ & $48.9 \%$ & $14.73 \%$ & $88.5 \%$ & $47.0 \%$ & $14.26 \%$ & $84.6 \%$ & $45.8 \%$ & $14.00 \%$ \\
\hline 10 & $89.8 \%$ & $47.3 \%$ & $14.35 \%$ & $86.4 \%$ & $46.3 \%$ & $14.12 \%$ & $76.8 \%$ & $43.4 \%$ & $13.49 \%$ \\
\hline 15 & $82.9 \%$ & $45.3 \%$ & $13.90 \%$ & $83.8 \%$ & $45.6 \%$ & $13.96 \%$ & $67.8 \%$ & $40.4 \%$ & $12.90 \%$ \\
\hline 20 & $74.9 \%$ & $42.8 \%$ & $13.37 \%$ & $80.8 \%$ & $44.7 \%$ & $13.76 \%$ & $57.3 \%$ & $36.4 \%$ & $12.19 \%$ \\
\hline \multirow[t]{2}{*}{25} & $67.5 \%$ & $40.3 \%$ & $12.88 \%$ & $77.9 \%$ & $43.8 \%$ & $13.57 \%$ & $47.8 \%$ & $32.3 \%$ & $11.54 \%$ \\
\hline & \multicolumn{3}{|c|}{ Tax increase from 0.3 to 0.6} & \multicolumn{3}{|c|}{ Capital shock, $50 \%$ remaining } & \multicolumn{3}{|c|}{ Combined effect } \\
\hline 5 & $87.6 \%$ & $46.7 \%$ & $14.20 \%$ & $42.6 \%$ & $29.9 \%$ & $11.18 \%$ & $33.5 \%$ & $25.1 \%$ & $10.54 \%$ \\
\hline 10 & $70.7 \%$ & $41.4 \%$ & $13.09 \%$ & $31.9 \%$ & $24.2 \%$ & $10.42 \%$ & $11.0 \%$ & $9.9 \%$ & $8.92 \%$ \\
\hline 15 & $52.1 \%$ & $34.2 \%$ & $11.83 \%$ & $19.1 \%$ & $16.0 \%$ & $9.51 \%$ & 0 & 0 & $8.11 \%$ \\
\hline 20 & $31.5 \%$ & $23.9 \%$ & $10.40 \%$ & $3.9 \%$ & $3.7 \%$ & $8.40 \%$ & 0 & 0 & $8.11 \%$ \\
\hline \multirow[t]{2}{*}{25} & $8.7 \%$ & $8.0 \%$ & $8.75 \%$ & 0 & 0 & $8.11 \%$ & 0 & 0 & $8.11 \%$ \\
\hline & \multicolumn{9}{|c|}{ Changing consumption to 0.9 of previous level } \\
\hline & \multicolumn{3}{|c|}{ Tax increase from 0.3 to 0.5} & \multicolumn{3}{|c|}{ Capital shock, 70 \% remaining } & \multicolumn{3}{|c|}{ Combined effect } \\
\hline 5 & $96.5 \%$ & $49.1 \%$ & $14.78 \%$ & $70.5 \%$ & $41.3 \%$ & $13.08 \%$ & $63.4 \%$ & $38.8 \%$ & $12.60 \%$ \\
\hline 10 & $92.6 \%$ & $48.1 \%$ & $14.52 \%$ & $72.1 \%$ & $41.9 \%$ & $13.18 \%$ & $55.1 \%$ & $35.5 \%$ & $12.04 \%$ \\
\hline 15 & $88.1 \%$ & $46.8 \%$ & $14.23 \%$ & $74.0 \%$ & $42.5 \%$ & $13.31 \%$ & $45.7 \%$ & $31.4 \%$ & $11.39 \%$ \\
\hline 20 & $83.0 \%$ & $45.3 \%$ & $13.90 \%$ & $76.2 \%$ & $43.2 \%$ & $13.46 \%$ & $35.0 \%$ & $25.9 \%$ & $10.64 \%$ \\
\hline \multirow[t]{3}{*}{25} & $77.2 \%$ & $43.6 \%$ & $13.52 \%$ & $78.9 \%$ & $44.1 \%$ & $13.63 \%$ & $23.0 \%$ & $18.7 \%$ & $9.79 \%$ \\
\hline & \multicolumn{9}{|c|}{ Changing consumption to 0.7 of previous level } \\
\hline & \multicolumn{3}{|c|}{ Tax increase from 0.3 to 0.5} & \multicolumn{3}{|c|}{ Capital shock, 70 \% remaining } & \multicolumn{3}{|c|}{ Combined effect } \\
\hline 5 & \multirow{5}{*}{\multicolumn{3}{|c|}{$\begin{array}{c}\text { Consumption decrease larger than } \\
\text { the tax increase. } \\
\text { Capital stock grows }\end{array}$}} & $79.0 \%$ & $44.1 \%$ & $13.64 \%$ & $71.8 \%$ & $41.8 \%$ & $13.16 \%$ \\
\hline 10 & & & & $94.2 \%$ & $48.5 \%$ & $14.63 \%$ & $76.4 \%$ & $43.3 \%$ & $13.47 \%$ \\
\hline 15 & & & & Capite & stock rec & ered & $81.5 \%$ & $44.9 \%$ & $13.81 \%$ \\
\hline 20 & & & & & & & $87.3 \%$ & $46.6 \%$ & $14.19 \%$ \\
\hline 25 & & & & & & & $93.9 \%$ & $48.4 \%$ & $14.61 \%$ \\
\hline
\end{tabular}


Appendix B: Results using Dynamic First Differences (DFD)

Table B1. The determinants of top income shares

\begin{tabular}{|c|c|c|c|c|c|c|c|c|c|c|}
\hline & (1) & $(2)$ & (3) & (4) & $(5)$ & (6) & (7) & $(8)$ & (9) & (10) \\
\hline & $\Delta$ top1 & $\Delta$ top1 & $\Delta$ top10-1 & $\Delta$ top10-1 & $\Delta$ bot 90 & $\Delta$ bot 90 & $\Delta$ top $1 / 10$ & $\Delta$ top $1 / 10$ & $\Delta$ top01/1 & $\Delta$ top01/1 \\
\hline \multirow[t]{2}{*}{$\Delta \mathrm{GDPpc}$} & $6.03 * * *$ & $6.92 * * *$ & $-10.44 * * *$ & $-8.08^{*}$ & 4.60 & 1.77 & $0.29 * * *$ & $0.36^{* * *}$ & 0.21 & $0.34 * *$ \\
\hline & $(1.85)$ & $(1.83)$ & (3.03) & $(4.79)$ & $(3.75)$ & $(5.46)$ & $(0.10)$ & $(0.12)$ & $(0.14)$ & $(0.16)$ \\
\hline \multirow[t]{2}{*}{$\Delta \mathrm{Pop}$} & -14.15 & $-16.75^{*}$ & -8.16 & -11.36 & 25.17 & $35.59 * *$ & $-0.68 *$ & $-0.90 * *$ & 0.11 & -0.33 \\
\hline & $(8.99)$ & $(8.81)$ & $(9.18)$ & $(9.49)$ & $(15.57)$ & $(14.22)$ & $(0.35)$ & $(0.36)$ & $(0.30)$ & $(0.31)$ \\
\hline \multirow[t]{2}{*}{$\Delta$ Govspend } & 5.29 & 9.78 & $-20.46 * * *$ & $-22.71 * *$ & $28.91 * * *$ & $24.43^{*}$ & 0.03 & 0.24 & -0.14 & 0.14 \\
\hline & $(7.63)$ & $(7.72)$ & (7.29) & $(9.45)$ & (9.69) & $(12.86)$ & $(0.27)$ & $(0.34)$ & $(0.40)$ & $(0.51)$ \\
\hline \multirow[t]{2}{*}{$\Delta$ Findev } & $1.04 *$ & $1.35 * * *$ & 0.03 & 0.06 & -1.13 & $-1.64 * *$ & $0.04 * *$ & $0.07 * * *$ & 0.01 & 0.00 \\
\hline & $(0.56)$ & $(0.42)$ & $(0.41)$ & $(0.45)$ & $(0.69)$ & $(0.64)$ & $(0.02)$ & $(0.02)$ & $(0.02)$ & $(0.02)$ \\
\hline \multirow[t]{2}{*}{$\Delta$ Openness } & -7.19 & -0.43 & 0.70 & 4.09 & -0.95 & -3.97 & 0.04 & -0.05 & -0.00 & 0.25 \\
\hline & $(4.57)$ & $(3.00)$ & $(3.73)$ & $(5.49)$ & $(5.35)$ & $(7.26)$ & $(0.13)$ & $(0.14)$ & $(0.12)$ & $(0.16)$ \\
\hline \multirow[t]{2}{*}{$\Delta$ Margtax 1} & & $-5.62 * * *$ & & $-4.99 *$ & & $11.37 * * *$ & & -0.14 & & $-0.30 * * *$ \\
\hline & & (1.72) & & $(2.75)$ & & (3.94) & & $(0.08)$ & & $(0.10)$ \\
\hline \multirow[t]{2}{*}{$\Delta 2$ top 1} & -0.03 & -0.02 & & & & & & & & \\
\hline & $(0.12)$ & $(0.18)$ & & & & & & & & \\
\hline \multirow[t]{2}{*}{$\Delta 2$ top $10-1$} & & & 0.21 & 0.24 & & & & & & \\
\hline & & & $(0.13)$ & $(0.15)$ & & & & & & \\
\hline \multirow[t]{2}{*}{$\Delta 2$ bot 90} & & & & & $0.20 *$ & $0.28 * *$ & & & & \\
\hline & & & & & $(0.11)$ & $(0.11)$ & & & & \\
\hline \multirow[t]{2}{*}{$\Delta 2$ top $1 / 10$} & & & & & & & 0.06 & -0.01 & & \\
\hline & & & & & & & $(0.14)$ & $(0.21)$ & & \\
\hline \multirow[t]{2}{*}{$\Delta 2$ top01/1 } & & & & & & & & & 0.16 & 0.09 \\
\hline & & & & & & & & & $(0.13)$ & $(0.18)$ \\
\hline Obs & 123 & 91 & 96 & 76 & 96 & 76 & 106 & 86 & 123 & 91 \\
\hline $\mathrm{R}$-squared & 0.54 & 0.68 & 0.53 & 0.49 & 0.58 & 0.67 & 0.71 & 0.64 & 0.59 & 0.62 \\
\hline
\end{tabular}

Notes: DFD estimations which allow for heteroskedasticity in the error terms. Standard errors in parentheses. ${ }^{* * *} \mathrm{p}<0.01,{ }^{* *} \mathrm{p}<0.05,{ }^{*} \mathrm{p}<0.1$. 
Table B2. The effects at different levels of economic development

\begin{tabular}{|c|c|c|c|c|}
\hline & $\begin{array}{c}(1) \\
\Delta \text { top1 }\end{array}$ & $\begin{array}{c}(2) \\
\Delta \text { top1 }\end{array}$ & $\begin{array}{c}(3) \\
\Delta \text { top10-1 }\end{array}$ & $\begin{array}{c}(4) \\
\Delta \text { top10-1 }\end{array}$ \\
\hline$\Delta \mathrm{GDPpc}$ & & $\begin{array}{c}5.97 * * * \\
(1.92)\end{array}$ & & $\begin{array}{c}-10.83 * * * \\
(3.01)\end{array}$ \\
\hline$\Delta$ Pop & $\begin{array}{c}-14.82 \\
(9.08)\end{array}$ & $\begin{array}{c}-15.78^{*} \\
(8.89)\end{array}$ & $\begin{array}{l}-7.89 \\
(9.20)\end{array}$ & $\begin{array}{c}-3.04 \\
(11.36)\end{array}$ \\
\hline$\Delta$ Govspend & $\begin{array}{c}3.17 \\
(7.85)\end{array}$ & $\begin{array}{c}5.60 \\
(7.76)\end{array}$ & $\begin{array}{c}-21.10^{* * *} \\
(7.77)\end{array}$ & $\begin{array}{c}-21.95 * * * \\
(7.51)\end{array}$ \\
\hline$\Delta$ Findev & $\begin{array}{l}1.09 * \\
(0.59)\end{array}$ & & $\begin{array}{c}0.05 \\
(0.42)\end{array}$ & \\
\hline$\Delta$ Openness & $\begin{array}{l}-7.63 \\
(4.61)\end{array}$ & $\begin{array}{l}-7.26 \\
(4.66)\end{array}$ & $\begin{array}{c}0.83 \\
(3.89)\end{array}$ & $\begin{array}{c}0.44 \\
(3.77)\end{array}$ \\
\hline$\Delta$ GDPpc $\times$ Lowdev & $\begin{array}{c}5.84 * * * \\
(1.86)\end{array}$ & & $\begin{array}{c}-9.63 * * \\
(3.71)\end{array}$ & \\
\hline$\Delta \mathrm{GDPpc} \times$ Meddev & $\begin{array}{c}6.89 * * * \\
(2.30)\end{array}$ & & $\begin{array}{c}-10.72 * * * \\
(3.43)\end{array}$ & \\
\hline$\Delta$ GDPpc $\times$ Highdev & $\begin{array}{c}4.09 \\
(3.52)\end{array}$ & & $\begin{array}{c}-11.93 * * * \\
(4.05)\end{array}$ & \\
\hline$\Delta$ Findev $\times$ Lowdev & & $\begin{array}{c}1.75 \\
(1.39)\end{array}$ & & $\begin{array}{l}-1.97 \\
(2.13)\end{array}$ \\
\hline$\Delta$ Findev $\times$ Meddev & & $\begin{array}{l}1.29 * * \\
(0.54)\end{array}$ & & $\begin{array}{l}-0.22 \\
(0.59)\end{array}$ \\
\hline$\Delta$ Findev $\times$ Highdev & & $\begin{array}{c}0.74 \\
(0.75)\end{array}$ & & $\begin{array}{c}0.71 \\
(0.51)\end{array}$ \\
\hline$\Delta 2$ top 1 & $\begin{array}{l}-0.02 \\
(0.12)\end{array}$ & $\begin{array}{l}-0.02 \\
(0.12)\end{array}$ & & \\
\hline$\Delta 2$ top10-1 & & & $\begin{array}{c}0.22 \\
(0.15) \\
\end{array}$ & $\begin{array}{c}0.21 \\
(0.13) \\
\end{array}$ \\
\hline F-test: Low $=$ Med $^{\mathrm{a}}$ & 0.56 & 0.74 & 0.73 & 0.45 \\
\hline F-test: Low $=$ High $^{\mathrm{a}}$ & 0.64 & 0.48 & 0.60 & 0.23 \\
\hline F-test: $\mathrm{Med}=\mathrm{High}^{\mathrm{a}}$ & 0.40 & 0.49 & 0.70 & 0.21 \\
\hline Obs & 123 & 123 & 96 & 96 \\
\hline $\mathrm{R}$-squared & 0.55 & 0.55 & 0.53 & 0.55 \\
\hline
\end{tabular}


Table B3. Does type of financial system matter?

\begin{tabular}{|c|c|c|c|c|c|c|c|c|c|c|}
\hline & (1) & (2) & (3) & (4) & $(5)$ & $(6)$ & (7) & (8) & (9) & (10) \\
\hline & $\Delta$ top1 & $\Delta$ top 1 & $\Delta$ top 1 & $\Delta$ top1 & $\Delta$ top1 & $\Delta$ top10-1 & $\Delta$ top10-1 & $\Delta$ top10-1 & $\Delta$ top10-1 & $\Delta$ top 10-1 \\
\hline \multirow[t]{2}{*}{$\Delta \mathrm{GDPpc}$} & $4.12 * *$ & $6.02 * * *$ & $5.40 * * *$ & $4.31 * *$ & $4.16^{* *}$ & $-8.11 * * *$ & $-10.50 * * *$ & -4.43 & $-7.60 * *$ & $-7.94 * *$ \\
\hline & $(1.80)$ & $(1.86)$ & $(1.95)$ & $(1.73)$ & $(1.77)$ & $(2.86)$ & $(3.07)$ & $(2.92)$ & $(3.03)$ & $(3.22)$ \\
\hline \multirow[t]{2}{*}{$\Delta$ Pop } & -1.72 & -14.44 & -0.52 & -3.88 & -3.94 & -5.54 & -8.57 & -3.42 & -6.12 & -6.52 \\
\hline & $(7.25)$ & $(9.29)$ & $(6.65)$ & $(7.41)$ & $(7.42)$ & $(6.48)$ & $(9.32)$ & $(7.08)$ & $(6.77)$ & $(6.91)$ \\
\hline \multirow[t]{2}{*}{$\Delta$ Govspend } & -1.51 & 6.29 & -2.04 & 2.65 & 2.89 & $-21.82 * * *$ & $-21.09 * * *$ & $-18.90 * *$ & $-19.37 * * *$ & $-18.99 * *$ \\
\hline & $(6.64)$ & $(7.71)$ & $(5.98)$ & $(6.81)$ & $(6.91)$ & (7.42) & $(7.41)$ & $(7.38)$ & $(7.24)$ & $(7.41)$ \\
\hline \multirow[t]{2}{*}{$\Delta$ Openness } & -3.76 & -5.11 & 2.99 & -2.36 & -2.30 & -2.17 & -0.46 & 3.77 & -2.02 & -2.07 \\
\hline & $(2.35)$ & $(3.80)$ & $(3.10)$ & $(2.23)$ & $(2.29)$ & $(2.05)$ & $(2.42)$ & $(3.60)$ & $(2.13)$ & $(2.14)$ \\
\hline \multirow[t]{2}{*}{$\Delta$ Bankdeposits } & 2.51 & & & & & 1.81 & & & & \\
\hline & $(1.61)$ & & & & & $(1.45)$ & & & & \\
\hline \multirow[t]{2}{*}{$\Delta$ Marketcap } & & $1.02 *$ & & & & & -0.13 & & & \\
\hline & & $(0.54)$ & & & & & $(0.45)$ & & & \\
\hline \multirow[t]{2}{*}{$\Delta$ Private credit } & & & 0.67 & & & & & 0.23 & & \\
\hline & & & $(0.84)$ & & & & & $(0.79)$ & & \\
\hline \multirow[t]{2}{*}{ Bank crisis } & & & & -0.87 & -0.87 & & & & 0.17 & 0.19 \\
\hline & & & & $(0.65)$ & $(0.66)$ & & & & $(0.58)$ & $(0.59)$ \\
\hline \multirow[t]{2}{*}{ Currency crisis } & & & & & -0.33 & & & & & -0.37 \\
\hline & & & & & $(0.62)$ & & & & & $(0.82)$ \\
\hline \multirow[t]{2}{*}{$\Delta 2$ top 1} & 0.02 & -0.04 & 0.03 & -0.01 & -0.01 & & & & & \\
\hline & $(0.08)$ & $(0.12)$ & $(0.14)$ & $(0.08)$ & $(0.08)$ & & & & & \\
\hline \multirow[t]{2}{*}{$\Delta 2$ top10-1 } & & & & & & 0.15 & 0.20 & 0.14 & 0.13 & 0.13 \\
\hline & & & & & & $(0.11)$ & $(0.13)$ & $(0.12)$ & $(0.11)$ & $(0.11)$ \\
\hline Obs & 153 & 125 & 126 & 155 & 155 & 120 & 98 & 108 & 122 & 122 \\
\hline $\mathrm{R}$-squared & 0.52 & 0.53 & 0.58 & 0.51 & 0.51 & 0.52 & 0.54 & 0.36 & 0.52 & 0.52 \\
\hline
\end{tabular}

Note: Splitting up Findev into the GDP shares of total bank deposits (Bankdeposits) and stock market capitalization (Marketcap). See also the notes of Table 1. 
Table B4: Are Anglo-Saxon countries different?

\begin{tabular}{|c|c|c|c|c|}
\hline & (1) & (2) & (3) & (4) \\
\hline & $\Delta$ top1 & $\Delta$ top 1 & $\Delta$ top10-1 & $\Delta$ top $10-1$ \\
\hline \multirow[t]{2}{*}{$\Delta \mathrm{GDPpc}$} & $6.17 * * *$ & $5.93 * * *$ & $-9.73 * * *$ & $-10.74 * * *$ \\
\hline & $(1.85)$ & $(1.82)$ & $(3.52)$ & $(3.15)$ \\
\hline \multirow[t]{2}{*}{$\Delta$ Pop } & -14.10 & -13.86 & -8.43 & -7.18 \\
\hline & $(9.19)$ & $(8.70)$ & $(9.26)$ & $(9.75)$ \\
\hline \multirow[t]{2}{*}{$\Delta$ Govspend } & 4.99 & 5.42 & $-21.16^{* * *}$ & $-20.74 * * *$ \\
\hline & $(6.94)$ & $(7.46)$ & $(7.38)$ & $(7.28)$ \\
\hline \multirow[t]{2}{*}{$\Delta$ Findev } & $1.03 *$ & $1.04 *$ & 0.02 & 0.02 \\
\hline & $(0.56)$ & $(0.56)$ & $(0.40)$ & $(0.41)$ \\
\hline \multirow[t]{2}{*}{$\Delta$ Openness } & -7.18 & -7.71 & -0.03 & 0.20 \\
\hline & $(4.60)$ & $(4.89)$ & $(4.14)$ & $(3.88)$ \\
\hline \multirow[t]{2}{*}{$\Delta$ GDPpc $\times$ Anglo-Saxon } & -0.58 & & -2.00 & \\
\hline & $(3.99)$ & & $(3.37)$ & \\
\hline \multirow[t]{2}{*}{$\Delta$ Openness $\times$ Anglo-Saxon } & & 1.12 & & 2.18 \\
\hline & & $(6.23)$ & & $(4.62)$ \\
\hline \multirow[t]{2}{*}{$\Delta 2$ top 1} & -0.03 & -0.03 & & \\
\hline & $(0.12)$ & $(0.12)$ & & \\
\hline \multirow[t]{2}{*}{$\Delta 2$ top $10-1$} & & & 0.22 & 0.21 \\
\hline & & & $(0.14)$ & $(0.14)$ \\
\hline Obs & 123 & 123 & 96 & 96 \\
\hline $\mathrm{R}$-squared & 0.55 & 0.55 & 0.53 & 0.53 \\
\hline
\end{tabular}


Table B5. Sample restrictions and alternative measures

\begin{tabular}{|c|c|c|c|c|c|c|c|c|c|c|}
\hline & (1) & $(2)$ & (3) & $(4)$ & (5) & (6) & (7) & $(8)$ & (9) & $(10)$ \\
\hline & $\Delta$ top1 & $\Delta$ top1 & $\Delta$ top1 & $\Delta$ top1 & $\Delta$ top1 & $\Delta$ top10-1 & $\Delta$ top10-1 & $\Delta$ top10-1 & $\Delta$ top10-1 & $\Delta$ top10-1 \\
\hline \multirow[t]{2}{*}{$\Delta \mathrm{GDPpc}$} & $5.24 * * *$ & $6.89 * *$ & $6.69 * * *$ & $-7.81^{*}$ & $4.36^{* *}$ & $-9.29 * * *$ & $-10.11 * * *$ & $-9.87 * *$ & 0.45 & $-10.46^{* * *}$ \\
\hline & $(1.83)$ & $(2.86)$ & $(1.59)$ & $(4.27)$ & $(1.67)$ & (3.39) & (3.17) & $(4.03)$ & $(4.38)$ & (3.05) \\
\hline \multirow[t]{2}{*}{$\Delta$ Pop } & -13.28 & -5.73 & -5.55 & $6.61 * * *$ & -6.03 & -7.21 & -5.88 & -7.98 & $-10.84 * * *$ & -8.32 \\
\hline & $(8.65)$ & $(8.93)$ & $(8.15)$ & $(2.24)$ & $(7.71)$ & $(8.95)$ & $(9.98)$ & $(10.61)$ & (3.49) & $(9.29)$ \\
\hline \multirow[t]{2}{*}{$\Delta$ Govspend } & 2.33 & 7.21 & $15.66 * *$ & -9.20 & 1.86 & $-20.36 * * *$ & $-18.25 * *$ & $-19.12 * *$ & $-17.28 *$ & $-20.69 * * *$ \\
\hline & $(6.47)$ & $(8.76)$ & $(7.42)$ & $(7.97)$ & $(6.52)$ & $(7.25)$ & (7.96) & $(9.10)$ & $(9.82)$ & $(7.41)$ \\
\hline \multirow[t]{2}{*}{$\Delta$ Findev } & 0.74 & 0.50 & $1.61 * * *$ & 2.88 & $1.30 * *$ & 0.04 & -0.11 & -0.04 & $-26.68 * * *$ & 0.05 \\
\hline & $(0.47)$ & $(0.41)$ & $(0.56)$ & $(7.28)$ & $(0.57)$ & $(0.41)$ & $(0.41)$ & $(0.47)$ & $(7.48)$ & $(0.41)$ \\
\hline \multirow[t]{2}{*}{$\Delta$ Openness } & 2.03 & 2.51 & -8.39 & $0.99 * *$ & -6.63 & 1.56 & & 4.61 & -0.12 & 0.91 \\
\hline & $(3.08)$ & $(5.25)$ & $(5.21)$ & $(0.40)$ & $(5.04)$ & $(3.82)$ & & $(5.74)$ & $(0.47)$ & $(3.81)$ \\
\hline \multirow[t]{2}{*}{$\Delta$ Margtax 2} & & & $-2.85 * *$ & & & & 5.33 & $-4.45 * * *$ & & \\
\hline & & & $(1.35)$ & & & & $(5.20)$ & (1.62) & & \\
\hline \multirow[t]{2}{*}{$\Delta$ Agrishare } & & & & -0.04 & & & & & $-0.34 * * *$ & \\
\hline & & & & $(0.10)$ & & & & & $(0.12)$ & \\
\hline \multirow[t]{2}{*}{$\Delta$ Patents } & & & & & 0.00 & & & & & 0.00 \\
\hline & & & & & $(0.00)$ & & & & & $(0.00)$ \\
\hline \multirow[t]{2}{*}{$\Delta 2$ top 1} & -0.03 & -0.02 & -0.09 & -0.06 & -0.03 & & & & & \\
\hline & $(0.16)$ & $(0.13)$ & $(0.11)$ & $(0.12)$ & $(0.12)$ & & & & & \\
\hline \multirow[t]{2}{*}{$\Delta 2$ top $10-1$} & & & & & & 0.19 & 0.18 & 0.24 & $0.25 *$ & 0.21 \\
\hline & & & & & & $(0.13)$ & $(0.14)$ & $(0.14)$ & $(0.13)$ & $(0.13)$ \\
\hline Restriction & Postwar & Tariffs & Margtax 2 & Agrishare & Patents & Postwar & Tariffs & Margtax2 & Agrishare & Patents \\
\hline Obs. & 111 & 106 & 101 & 114 & 112 & 92 & 85 & 80 & 88 & 96 \\
\hline $\mathrm{R}$-squared & 0.63 & 0.54 & 0.62 & 0.62 & 0.61 & 0.43 & 0.54 & 0.59 & 0.57 & 0.53 \\
\hline
\end{tabular}

Note: Postwar = sample is 1950 onwards, $\sim$ Japan = Japan excluded from sample and Margtax2 replaces Margtax1. See the notes of Table 1. 